\title{
K odňatiu právomoci Ústavného súdu SR posudzovat' ústavné zákony - kritické reflexie
}

\author{
Lalík,T.*
}

LALÍK, T.: K odňatiu právomoci Ústavného súdu SR posudzovat' ústavné zákony kritické reflexie. Právny obzor, 104, 2021, č. 2, s. 116 - 140.

\begin{abstract}
Nullifying the power of the Slovak Constitutional Court to review unconstitutional amendments - a critique. The article critically reviews the last constitutional amendment that took away the power of the Slovak Constitutional Court to review unconstitutional amendments. It argues that such amendment is neither in line with constitutionalism nor with democracy. In particular the paper critically examines the unbound power of the parliament to amend the Constitution, its claim on sovereignty and its uniqueness in representing the People. The article explores in what way constitutional courts in general are representative and thus democratic institutions, what the role of the courts in constitutional project is and how to approach the delicate issue of the substantive core of the Slovak Constitution. The author claims that the judgment PL. ÚS 21/2014 improved the Slovak Constitution in terms of rigidity, democracy and effective control of the parliament and as a result it deserved to be respected by the other branch of the government.
\end{abstract}

Key words: unconstitutional amendments, democracy, referendum, constitutionalism

„Nikto nemôže tvrdit', že stelesňuje vôl'u l'udu, či hovorí autoritatívne v jeho mene, ani nikto nemôže uvádzat', že je jediným vyjadrením kritiky a nespokojnosti l’udu. “

Pierre Rosanvallon

V decembri minulého roka dostalo slovenské ústavné právo nemilý darček - ústavný zákon č. 422/2020 Z. z., ktorý inter alia obral stavný súd SR (d’alej ako ústavný súd) o právomoc posudzovat' súlad ústavného zákona s ústavou. $\mathrm{V}$ dôvodovej správe, na ktorú sa v článku budem odvolávat', parlament uviedol: „Ústavný súd si ju (túto právomoc; pozn. T. L.) z ústavy vyvodil ako implicitnú právomoc nadinterpretovaním slova ,zákon" v čl. 125 ods. 1 písm. a), a to na základe úvah o potrebe ochrany tzv. materiálneho jadra ústavy a o tom, že povereným na takúto ochranu by mal byt práve ústavný súd samotný (pozri PL. ÚS 21/2014). Tento postup ústavného súdu bol kritizovaný (...) Postup ústavného súdu síce našiel aj podporovatel'ov, kedžze je však otázka existencie prieskumu ústavodarnej činnosti koncepčnou otázkou v plnej dispozícii ústavodarcu, tento má priestor reagovat' ,zexplicitnením “ existujúcej koncepcie, ale aj jej zmenou.

Ústavodarca navrhovanou zmenou robi explicitným formát, v ktorom ústavodarnú činnost' priamo legitimizovaných zástupcov l’udu nepreskúmava ústavný súd. Naopak, je ňou viazaný ako referenčnou a hodnotovou rovinou, na pozadi ktorej vykonáva svoju

* Doc. JUDr. Tomáš L' a 1 í k, PhD., Katedra ústavného práva, Právnická fakulta, Univerzita Komenského v Bratislave. 
činnost', a ktorú chráni. Ak teda ústavodarca výslovne ústavný súd poveruje kontrolou zákonodarcu, a to aj s vedomím, že nevolený súdny orgán bude ,rušit” činnost' priamo legitimovaného normotvorcu, pnutie medzi princípom demokracie a právneho štátu rieši $v$ strete ústavodarcu a ústavného súdu naopak, v prospech ústavodarcu. Ústavný súd je totiž produktom ústavodarnej činnosti, rovnako ako zákonodarca. Ústavodarca je jej predpokladom. To neznamená, že v ústave neexistujú poistky proti činnosti ústavodarcu. Prvým a posledným ochrancom „ústavnosti ústavy“ však v zvolenej koncepcii nie je ústavný súd, ale l'ud, respektive občianska spoločnost'."1

Predmetný článok rozvádza kritiku tohto počinu, ktorá bola sčasti publikovaná aj inde. ${ }^{2}$ Článok pojednáva o tom, že vylúčenie kontroly ústavného zákona s ústavou a koncepcia parlamentu ako jediného ústavodarcu, je rozpore s hodnotami konštitucionalizmu a demokracie. Okrem napätia s týmito hodnotami, článok komentuje aj niektoré aspekty kritiky, ktoré vyvolal nález sp. zn. PL. ÚS 21/2014. Ciel'om príspevku je dat' do pozornosti alternatívne vnímanie právnych a faktických súvislostí, ktoré odzneli vo verejnom diskurze vrátane dôvodovej správy. Začneme najprv formálnou argumentáciou delegovaného ústavodarcu.

\section{Z ČOHO SI ÚSTAVNÝ SÚD VLASTNE VYVODIL SVOJU PRÁVOMOC A NIEKTORÉ PROCESNÉ OTÁZKY V NÁLEZE PL. ÚS 21/2014}

Delegovaný ústavodarca $\mathrm{v}$ dôvodovej správe uviedol chybu. Z hl'adiska formy si prekladatel' ústavného zákona zrejme nedal námahu s tým, aby sa poriadne zoznámil so znením nálezu sp. zn. PL. ÚS 21/2014. Ak by tak urobil, nemohol by potom v dôvodovej správe tvrdit', že si ústavný súd vyvodil svoju právomoc nadinterpretovaním čl. 125 ods. 1 písm. a) ústavy. Ako vyplýva zo samotného nálezu, ústavný súd si síce vyvodil právomoc posudzovat' ústavný zákon s ústavou, nepoužil však čl. 125 ústavy, ale článok 124 ústavy, čo je rozdiel. ${ }^{3}$ Je vel'mi znepokojujúce, že takýto závažný fakt si delegovaný ústavodarca nevšimol. Pokračujúc v samotnej kontrole súladu ústavného zákona s ústavou (a jej materiálnym jadrom) už použil právne normy upravujúce konanie o súlade právnych predpisov, teda čl. 125 ústavy, na základe analógie legis. ${ }^{4}$

V tomto smere je možné namietat' aj tvrdenie dvojice autorov M. Káčer a J. Neumann, že ústavný súd mohol použit’ už zrušený § 40 zákona č. 38/1993 Z. z. len na konanie podl’a čl. 125 ústavy, a nie na konanie podl'a čl. 124 ústavy. ${ }^{5}$ Ako vyplýva z bodu 106

\footnotetext{
${ }^{1}$ Dôvodová správa k ústavnému zákonu č. 422/2020 Z. z., s. 6 a 7.

${ }^{2}$ Por. napr. DRUGDA, Š. On Collision Course with the Material Core of the Slovak Constitution [202102-03]. Dostupné na internete: $<$ On Collision Course with the Material Core of the Slovak Constitution Verfassungsblog>; LALÍK, T. Slovakia on its way to Illiberal Democracy: Nullifying the Power of the Constitutional Court to Review Constitutional Amendments [2021-02-03]. Dostupné na internete: $<$ I CONnect - Slovakia on its way to Illiberal Democracy: Nullifying the Power of the Constitutional Court to Review Constitutional Amendments (iconnectblog.com)>

${ }^{3}$ Por. body 82, 87, 90 nálezu sp. zn. PL. ÚS 21/2014.

${ }^{4}$ Bod 106 nálezu sp. zn. PL. ÚS 21/2014.

${ }^{5}$ KÁČER, M. - NEUAMNN, J. Materiálne jadro v slovenskom ústavnom práve. Doktrinálny disent proti zrušeniu sudcovských previerok. Praha : Leges, 2019, s. 42.
} 
komentovaného nálezu Ústavného súdu, § 40 bol plne aplikovatel'ný na daný prípad, pretože ústavný súd postupoval v predmetnom konaní podl'a čl. 125 ústavy na základe analógie legis. Nič na tom nemení ani skutočnost', že si právomoc vyvodil z čl. 124 ústavy. Tento postup bol logický a správny, pretože použitie analógie legis je možné, ak (i) určitá skutočnost' nie je právne upravená; (ii) existuje právna regulácia, ktorá túto (právom neupravenú) skutočnost' reguluje podobne v určitých smeroch a nakoniec (iii) existuje väzba medzi právom neregulovanou skutočnost'ou, ktorá má podobné alebo rovnaké právne dôsledky ako skutočnost', ktorá je priamo regulovaná právnymi normami. ${ }^{6}$ Tento prípad splnil všetky vyššie uvedené predpoklady na použitie analógie legis, pretože konanie o súlade stavného zákona s ústavou nebolo právne regulované; konanie podl'a čl. 125 reguluje predmet konania o súlade ústavných zákonov s ústavou v zásade rovnako a nakoniec dôsledky oboch skutočností sú identické - aj v konaní podl'a čl. 125 aj v konaní o súlade ústavného zákona s ústavou sa sleduje neústavnost' (zrušenie) právnej regulácie.

Pokračujúc v argumentácii o (ne)správnom použití § 40 už zrušeného zákona č. 38/1993 Z. z. je dôležité uviest' jeho plné znenie: „Ak Ústavný súd pri rozhodovaní podl'a čl. 125 Ústavy zistí nesúlad preskúmavaného právneho predpisu nižšej právnej sily s právnym predpisom vyššej právnej sily alebo s medzinárodnou zmluvou, a pritom zistí nesúlad aj d'alšich právnych predpisov s predpismi vyššej právnej sily alebo s medzinárodnou zmluvou, vydá nález o zistenom nesúlade aj týchto d’alších právnych predpisov.“ Z doslovného výkladu predmetného ustanovenia je možné príst' k záveru, že ústavnému súdu umožňoval zrušit’ neobmedzené množstvo prípadov za dvoch predpokladov (okrem právne perfektného návrhu): (i) ak zistil nesúlad preskúmavaného (teda navrhovatel'om napadnutého) právneho predpisu a (ii) počas samotnej kontroly zistil aj neústavnost' iných právnych predpisov. Dokonca a na rozdiel od súčasného znenia $§ 89$ zákona č. 314/2018 Z. z. ústavný súd pri použití § 40 zákona č. 38/1993 Z. z. nebol viazaný ani tými istými referenčnými kritériami, čím mohol napr. vyhoviet' návrhu pre rozpor s čl. 26 ústavy a skonštatovat' napr. neústavnost' d’alších zákonov či právnych predpisov pre rozpor s čl. 12 ods. 2 ústavy. Textom nebol nijako obmedzený.

To že táto právomoc bola využívaná reštriktívne zo strany ústavného súdu , nemení nič na tom, že znenie právnej úpravy mu umožňovalo vyhlásit' za neústavné neurčité množstvo právnych predpisov, čo ústavný súd v náleze PL. ÚS 21/2014 aj urobil. Ad absurdum, ak by ústavný súd vykonával kontrolu extenzívne, tak by mohol zrušit' aj podstatnú čast' právneho poriadku alebo celé právne odvetvia. Teda ani argument M. Káčera a J. Neumanna o funkčnej neprepojenosti medzi posudzovaným právnym predpisom, ktorý je neústavný, a d’alšími právnymi predpismi ${ }^{8}$ nie je namieste, pretože text $\S 40$ zákona č. 38/1993 Z. z. bol natol'ko široký, že vlastne otvoril bránu Ústavnému súdu k neobmedzenej kontrole ústavnosti za splnenia vyššie uvedených jednoduchých predpokladov.

\footnotetext{
${ }^{6}$ Por. MORAWSKI, L. Zasady wykładni prawa. 2. wyd. Toruň : Dom Organizatora, 2010, s. 230.

${ }^{7}$ Por. LALÍK, M. - LALÍK, T. Zákon o Ústavnom súde Slovenskej republiky. Komentár. Bratislava : Wolters Kluwer, 2019, s. 285-288.

${ }^{8}$ Materiálne jadro v slovenskom ústavnom práve, s. 43-44.
} 
Navyše, otázka o funkčnej prepojenosti sa týka oblasti, v ktorej musí mat' ústavný súd priestor na diskréciu, pretože celý právny poriadok je funkčne prepojený. Celkovo je tak otázka o možnosti zásahu ústavného súdu do ústavného zákona otázkou o rozsahu jeho diskrécie, resp. úlohe, ktorú má ústavný súd plnit' v demokratickom a právnom štáte. K tejto otázke sa dostaneme trochu neskôr. Teraz sa zameriame na otázku suverenity, ktorá je z hl'adiska vzt’ahu parlament - ústavný súd - l'ud úplne kl'účová.

\section{KTO JE VLASTNE NA SLOVENSKU SUVERÉN ALEBO O ZASTUPOVANÍ LUDU A DEMOKRACII}

Parlament pri koncipovaní dôvodovej správy vychádza z predpokladu, že otázka prieskumu ústavodarnej činnosti je koncepčnou otázkou $\mathrm{v}$ plnej dispozícii ústavodarcu. Z toho vyplýva, že sám parlament (qua ústavodarca) sa môže rozhodnút', či a ako s koncepciou materiálneho jadra naloží, ako aj to, kto bude vykonávat' ultimátnu ochranu ústavnosti.

Táto premisa má niekol'ko chýb. Tou prvou je, že sám parlament, podobne ako ústavný súd, je len produktom ústavy. Uvedené je možné demonštrovat' na hypotetickej možnosti samotného parlamentu zrušit' samého seba. Na otázku, či sám parlament môže zrušit' samého seba a napr. zaviest' diktatúru exekutívy (ktorá by bola napr. volená), musíme z pozície právneho pozitivizmu odpovedat' kladne. Takže ked' parlament môže legálnou cestou zrušit’ samého seba, znamená to tol'ko, že nie je „predpokladom“ ústavy (dôvodová správa asi chcela použit’ termín „tvorca“, ale zdalo sa jej to príliš silné), ale len jej dôsledkom (produktom).

Čo je však dôležitejšie, suverén zrušit' sám seba, ak má existovat' ako suverén, nemôže - prestal by existovat' ako suverén. Na druhej strane, ak prijmeme koncepciu l'udu ako suveréna, l'ud sám seba zrušit' nemôže, pretože je empirickou entitou, ktorá existuje nezávisle od práva, politického systému a jeho inštitúcií. Aj z tohto pohl'adu je l’ud ako suverén „večný“ a trvale prítomný, podobne ako Boh v teologických náukách. Preto koncepcia ultimátnej suverenity l’udu (a nie parlamentu) je logicky správna a v demokracii jediná možná.

Za uvedeným záverom hovorí aj porovnávacie ústavné právo. Spolkový ústavný súd v rozhodnutí z roku 2017 o nerozpustení nemeckej národnosocialistickej strany výslovne uviedol, že nebude $\mathrm{v}$ rozpore $\mathrm{s}$ večnou klauzulou demokracie taká ústavná úprava, ktorá by zrušila nemecký parlament a nahradila ho určitou formou plebiscitnej demokracie. ${ }^{9}$ Pritom rovnako ako v prípade Slovenska aj nemecký základný zákon v roku 1949 prijal nemecký parlament, pričom sa referendum o potvrdení základného zákona nikdy nekonalo.

Z uvedeného je možné konštatovat', že parlament konajúci tak, že mení alebo dopíňa ústavu, je vždy len delegovaný ústavodarca - produkt ústavy. Suverénom je len l'ud (čl. 2 ods. 1 ústavy), ktorý parlament môže len zastupovat', čo je tiež otázne. Najprv sa pozrieme na to, či l'ud ako ničím neobmedzený suverén je vôbec zastupitel'ný.

\footnotetext{
${ }^{9}$ Rozsudok zo 17. januára 2017, 2 BvB 1/13, § 543.
} 
V zmysle koncepcie J. J. Rousseaua je suverenita nezastupitel'ná a nedá sa delegovat' alebo zastupovat'. Dokonca aj pri príprave novej ústavy je ústavodarné zhromaždenie, ktoré má za úlohu vypracovat' ústavu, vždy len delegovaným ústavodarcom a nie suverénom. Preto je konštituanta vždy obmedzená nielen tým, že má povinnost' vypracovat' novú ústavu podl'a inštrukcií z referenda, ${ }^{10}$ ale aj tým, že sa nemôže transformovat' na samotného suveréna. ${ }^{11}$ Suverénom môže byt' v demokracii len l'ud ako empirická (existujúca) entita; suverenita je nezastupitel'ná a nedá sa delegovat'. J. Colón-Ríos hovorí, že nikto iný okrem zhromaždenia všetkých občanov na jednom mieste nemôže tvrdit', že je suverénom. ${ }^{12}$ Teda ak by sa všetci občania Slovenska stretli na vel'kej lúke, neboli by viazaní žiadnymi právnymi predpismi, resp. by si mohli prijat' vlastné pravidlá spravovania celej spoločnosti, ak by, samozrejme, chceli, pretože by vykonávali pôvodnú a žiadnymi právnymi predpismi neobmedzenú moc.

Autori M. Káčer a J. Neumann varujú pred takouto bezprostrednou suverenitou, ktorá je podl’a nich nevyhnutne spojená s násilím. ${ }^{13}$ Sú však takéto obavy namieste v 21 . storočí v európskej krajine? Revolúcia ako nevyhnutné spojivo s pôvodnou ústavodarnou mocou však nie je jednorazovým násilím, nie je un grand soir, ako to bývalo v d'alekej minulosti. Revolúcia a samotný radikalizmus, ktorý stojí za ňou, sa pretransformovali na každodennú aktivitu ako tvrdí P. Rosanvallon. Byt' radikálny znamená dnes vydržat' v kritike mocných a snažit' sa zobudit' pasívnych občanov. Byt' revolučný je ukazovat' prstom hanby každý deň, a nie mierit' delom na pevnost' moci pri poslednom útoku. ${ }^{14}$

Preto idea revolúcie ako súčasti pôvodnej ústavodarnej moci síce hypoteticky môže byt' revolučná (ktorou bola v minulosti), ale v súčasnosti takou nie je. ${ }^{15} \mathrm{~V}$ globálnom rozmere súčasné (ne)úspešné aktivity prijímania nových ústav vo svete (napr. Island, Čile a i.) v sebe neobsahovali násilie či násilnú revolúciu, ale mali či majú formu plne demokratickú so zapojením l'udu vo forme konzultácií, občianskych zhromaždení, referend pred ústavodarným procesom (či prijat' novú ústavu a kto ju má vypracovat'), ako aj po ňom (súhlas/nesúhlas s novou ústavou) atd'. Teda akási násilná a krutá revolúcia, ktorá nevyhnutne musí sprevádzat ústavodarný proces, pred čím varujú M. Káčer a J. Neumann, je dnes mýtom. Koniec koncov nie sú známe prípady, že by sa ústavodarný proces v roku 1992 niesol na Slovensku v rovine násilnej revolúcie, obetí, občianskej vojny atd’.

Ďalšou chybou dôvodovej správy je nesprávne vnímanie demokracie. Čl. 1 ods. 1 ústavy deklaruje, že náš štát je demokratický, pričom suverenita patrí l’udu (čl. 2 ods. 1

\footnotetext{
${ }^{10}$ Napr. akú ústavu má prijat' - s participatívnymi prvkami demokracie, so sociálnymi právami, ktoré sú súdne vynútitel'né atd'. V tejto súvislosti je možné uviest' aj referendum o Brexite - orgány verejnej moci museli za akýchkol'vek podmienok rešpektovat' vôl'u l'udu a z EÚ vystúpit'.

${ }^{11}$ Por. COLÓN - RÍOS, J. Arato's Adventures: between sovereignty and constituent power. In Journal for constitutional theory and legal philosophy, 41/2020, § 25-27 [2021-02-03]. Dostupné na internete: <https:// journals.openedition.org/revus/6257>.

12 Tamtiež, $\S 31$.

${ }^{13}$ Materiálne jadro v slovenskom ústavnom práve, s. 131.

${ }^{14}$ ROSANVALLON, P.: Counter-Democracy. A Politics in an Age of Distrust. Cambridge: Cambridge University Press, 2012, s. 255.

${ }^{15}$ TUSHNET, M.: Peasants with pitchforks, and toilers with Twitter: Constitutional revolutions and the constituent power. In ICON. roč. 13, č. 3, 2015, s. 653.
} 
ústavy) . Čo vlastne demokracia znamená? Demokracia je spôsobilost' celého l’udu konat' vo sfére verejnosti, pričom toto konanie má reálnu podobu. Ide o režim, kde l'ud má kolektívnu spôsobilost' vykonávat' zmeny vo verejnej sfére. Ide o kolektívnu silu a schopnost' konat' na verejnosti a poprípade znovu vytvorit' verejnú sféru prostredníctvom konania. ${ }^{16}$ Ultimátnym ciel'om demokracie je ukončit' l'udskú slepotu a nemohúcnost' jediným pohybom. Snahou demokracie je urobit' l'ud prítomným a splnomocnit' ho, pretože demokracia je panstvo nad samým sebou a chápaním sveta. ${ }^{17}$

V súčasnosti, ked’ nedôvera k verejným inštitúciám láme celosvetové rekordy, autori venujúci sa demokracii opúšt'ajú názor, že vôl'a l'udu sa môže ukázat' výlučne v parlamente. Súčasným trendom je opak, a to, že vôl’a l’udu je prítomná v rôznych inštitúciách (vrátane ústavného súdu, na čo poukážem neskôr). Okrem formálnych inštitúcií má l’ud svoje vlastné neformálne a neštruktúrované prejavy participácie a politickej zaangažovanosti, akými sú demonštrácie, štrajky, protesty, petície, využívanie sociálnych sietí, činnost' médií a iné. Demokracia zužujúca sa na vol'by a referendum (obe vykonávané len raz za čas) je karikatúrou vlády l’udu.

P. Rosanvallon vidí občanov-voličov ako dozorcov, držitel'ov veta a sudcov. V tejto súvislosti tvrdí, že l'ud sa vytratil z formálnej autority ústavy a na zistenie komplexného stavu moci je nutné sledovat' okrem formálnych inštitútov (vol'by, parlament a iné orgány) aj nepriamu moc v tzv. protidemokracii (counterdemocracy). ${ }^{18}$ Tá pozostáva z materiálnej sily praktickej reakcie (priamej odpovede), je stála a nie je inštitucionálne obmedzená. ${ }^{19}$ Protidemokratické inštitúcie, akými sú okrem iných aj ústavné súdy (ale aj mnohé iné, napr. súkromné či mimovládne inštitúcie), spôsobujú dve reakcie: politickú vitalitu, pretože tieto inštitúcie umožňujú jednak zapojenie l'udu do rozhodovacích procesov a zdôrazňujú oddelenost' od oficiálnych inštitúcií, ktoré majú v „popise práce“ zastupovat' l'ud. ${ }^{20}$ Demokratická aktivita sa rozširuje mimo voleno-zastupitel'ské inštitúcie. ${ }^{21}$

Samotná ústava rozoznáva priamu a zastupitel'skú demokraciu. Skutočnost', že ústava rozlišuje medzi priamou a nepriamou demokraciou, znamená, že l’ud koná aj mimo parlamentu. Ústavné a podústavné právo sú založené na fundamentálnom a koncepčnom rozdiele medzi l’udom (zdrojom moci) a vládcami, ktorí v mene l’udu vykonávajú politickú moc. Vôl'a l'udu je vyjadrená v ústave a nie v zákonoch. ${ }^{22}$

Azda najväčšiu kritiku si parlament zaslúži za to, že sám seba považuje za (jediného) zástupcu l'udu. Pri tomto konštatovaní sa sčasti ozýva (anachronický a nesprávny) argument R. Procházku, že ak l'ud nekoná priamo, koná prostredníctvom parlamentu. ${ }^{23} \mathrm{Ak}$ je

${ }^{16}$ Por. OBER, J. The Original Meaning of "Democracy": Capacity to Do Things, not Majority Rule. In Constellations, roč. 15, č. 1, 2008, s. 7 .

${ }^{17}$ ROSANVALLON, P. Counter-Democracy, s. 309.

${ }^{18}$ Tamtiež, s. 17.

19 Tamtiež, s. 25.

${ }^{20}$ Tamtiež, 253.

${ }^{21}$ Tamtiež, s. 249.

${ }^{22} \mathrm{~K}$ tomuto rozdielu a východiskovému predpokladu ústavy a konštitucionalizmu por. publikáciu GRIMM, D. Constitutionalism. Past, Present, and Future. Oxford : Oxford University Press, 2016.

${ }^{23}$ PROCHÁZKA, R. L’ud a sudcovia v konštitučnej demokracii. Plzeň : Aleš Čeněk, 2013, s. 60. 
však parlament zástupcom l'udu, nemôže popriet' existenciu samotného zastúpeného. Ako však skutočnú vôl'u l'udu zist'ovat'? Práve neexistencia mechanizmu zist'ovania vôle l'udu sa môže zmenit' na situáciu, ktorú niektorí autori nazývajú inverziou zastupitel'stva. ${ }^{24}$ Ide o situáciu, ked' parlament nie je zástupcom l’udu, ale l'ud je zástupcom parlamentu. Za vôl'u l'udu je považované to, čo za ňu označí parlament. Pri splynutí l'udu a jeho zástupcu reprezentácia nie je ničím obmedzovaná a parlament môže za vôl'u l'udu označit' čokol'vek. Splynutie vôle l'udu a parlamentu je však znakom totalitarizmu, a nie demokracie. ${ }^{25}$

Už skôr som sa venoval otázke, či vôl'a l'udu môže byt' z hl'adiska súhlasu v súlade $\mathrm{s}$ vôl'ou parlamentu, a prišiel som k záveru, že nie, a to z nasledujúcich dôvodov: $\mathrm{z}$ titulu abstraktného (a teda fiktívneho) stotožnenia l’udu s jeho zástupcom (čo je v dnešnej pluralistickej a atomizovanej spoločnosti nemožné a čo bolo asi možné pri zastupovaní úzkej sociálnej skupiny v 19. storočí); neexistujúcim mechanizmom vyvodzovania zodpovednosti voči zástupcom (politická zodpovednost' je len fingovaná zodpovednost ${ }^{26}$ ); stratou identity medzi zástupcami a l'udom (zástupcovia sú kvalitatívne odlišní od zastúpených), ako aj stratou dôvery l'udu voči parlamentu či iným orgánom verejnej moci. ${ }^{27}$ Vo vzt’ahu k poslednému argumentu sa žiada dodat', že politici, novinári a aj niektorí akademici zvýrazňujú nedôveru voči súdom, pričom opomínajú mieru nedôvery, ktorú l'ud prechováva voči parlamentu a vláde bez ohl'adu na to, ktorá politická strana alebo koalícia vedie krajinu. ${ }^{28}$

P. Rosanvallon spomína v tomto smere fenomén desakralizácie volieb. V klasickej teórii a praxi zastupitel'skej demokracie úlohou voličov bolo legitimizovat' tých, ktorí vykonávajú mandát. Zvolení zástupcovia následne získali vel'kú mieru autonómie. Uvedené už nie je realitou, pretože voliči dávajú mandát vo svete, ktorý je menej predvída-

${ }^{24}$ Por. KOKEŠOVÁ, J. Ústavní soud a reprezentace lidu: abduktivní interference. In Právník, č. 6, 2019, s. 577 a tam cit. literatúra. Dokonca ani vo Vel'kej Británii ako kolísky tzv. parliamentary supremacy, nie je koncept nadradenosti parlamentu po rozhodnutiach Najvyššieho súdu Vel'kej Británie vo veciach Miller I a Miller II vnímaný ako na Slovensku; por. ELLIOTT, M. Constitutional Adjudication and Constitutional Politics in the United Kingdom: The Miller II Case in Legal and Political Context. In European Constitutional Law Review, roč. 16, č. 4, 2020.

${ }^{25}$ Ako potom hodnotit’ výrok ministerky spravodlivosti M. Kolíkovej, ktorá tvrdí, že: „Ten, kto tú legitimitu má, je l’ud, to znamená parlament.“ [2021-02-03]. Dostupné na internete: <Kolíková: Ústavný súd nemá čo vysvetl'ovat', čo je Ústava - Slovanské Noviny (slovanskenoviny.sk) >.

${ }^{26}$ Niektorí z autorov, ktorí sa venujú problematike zastupitel'skej demokracie, degradujú vol’ný mandát poslancov na bezobsažnú právnu fikciu; SZYMANEK, J. Mandat parlamentarny (reinterpretacja ujęć klasycznych). In Przegład sejmowy, roč. 100, č. 5, 2010, s. 127

${ }^{27}$ Pre podrobnosti por. L'ALÍK, T. Ústavný súd a parlament v konštitučnej demokracii. Bratislava : Wolters Kluwer, 2015, s. 24-44.

${ }^{28} \mathrm{~V}$ tejto súvislosti je rovnako na pováženie, že autori M. Káčer a J. Neumann nedôveru voči parlamentu a vláde „zval'ujú“ na globálne trendy a osobitosti krajiny (s. 52) namiesto toho, aby priznali, že súdy požívajú rovnakú mieru dôvery alebo nedôvery ako ostatné inštitúcie. Napr. aj polícia v SR požíva najnižšiu dôveru spomedzi všetkých členských štátov EÚ, vláda a parlament sú na tom rovnako ako súdy; dostupné na internete: $<$ Slováci neveria svojim inštitúciám. Dôvera v políciu je u nás dokonca najmenšia z celej EÚ | Noviny.sk $>$ [202102-03]. Nie je pritom rozhodujúce to, že si parlament pravidelne volíme na rozdiel od sudcov, resp. že sudcovia majú výhody oproti iným zložkám moci. Ak je nedôvera symptomatická pre inštitúciu bez ohl'adu na to, kto je v nej, čo je aj prípad SR, tak úvahy o legitimite či potrebe navrátit' dôveryhodnost' sú selektívne a irelevantné. Povedané inak, zatial' všetko nasvedčuje tomu, že nedôvera na Slovensku je inštitucionálna a nie osobná. 
tel'ný a nedefinovatel'ný disciplinovanými politickými organizáciami s trvalými platformami, ktoré ponúkajú jasné portfólio politického výberu. Vol'by sa zdeformovali na spôsob výberu zástupcov s nízkou legitimitou, ktorých konanie musí byt’ permanentne kontrolované každý deň a v každom jednom prípade. ${ }^{29}$ Demokracia už nie je výberom zástupcov, ale ich neustálou a efektívnou kontrolou výkonu ich mandátu. ${ }^{30}$ Ústavné súdy plnia $\mathrm{v}$ tejto demokracii práve kontrolnú funkciu.

Najdôležitejší prvok v diskusii predstavuje skutočnost', že l’ud a parlament sú dve rôzne a od seba de facto nezávislé entity. Nie je pritom možné si ich v ústavnom štáte zamieňat' alebo akosi apriórne akceptovat', že vôl'a l'udu je aj vôl'ou parlamentu. Svojim študentom niekedy hovorím, že ak si nič iné nezapamätajú z ústavného práva, aby nezabudli, že v ústave je reflektovaná vôl'a l’udu, ktorá mu garantuje základné práva a slobody (a contrario takmer nijaké povinnosti) a zároveň výkon akejkol'vek moci je dopredu obmedzovaný samotnou ústavou. Vôl'a parlamentu ako orgánu verejnej moci je reflektovaná v jeho legislatívnej činnosti. Už z toho expozé je vidiet' možnost' konfliktu medzi vôl'ou parlamentu a vôl'ou l'udu, pričom tá prvá, musí byt' v súlade s druhou.

Ak uznáme, že existuje rozdiel medzi l'udom a jeho zástupcami, resp. že vôl'a l'udu sa automaticky nezhoduje s vol'ou jeho zástupcov pri kontrole zákonov, tak musíme aj uviest', že tento predpoklad existuje aj pri posudzovaní súladu ústavných zákonov s ústavou.

Kl'účovým problémom slovenského ústavného poriadku je flexibilita zmien ústavy, ktorá je notorický známa a v doktríne silno kritizovaná niekol'ko desat'ročí. ${ }^{31}$ Koncepcia čl. 86 a) ústavy vlastne nepriaznivo vplýva na demokratickú legitimitu celého ústavného systému, pretože pri ústavných zmenách koná výlučne parlament, pričom l’ud (ani iný orgán verejnej moci) nie je do tejto aktivity vôbec zapojený. Zmena ústavy je len fasáda (forma), ale materiálne (ani formálne) nie je rozdiel medzi zákonodarcom a delegovaným ústavodarcom, pretože ide o ten istý orgán - parlament. Úspešná regulácia ústavných zmien musí byt' kompromisom medzi rizikom erózie ústavy prostredníctvom prílišnej rigidity alebo flexibility, ${ }^{32}$ čo nie je prípad Slovenska, ktoré má najflexibilnejšiu ústavu v Európe a šiestu na svete.

Doktrinálny a v podstate aj judikatórny vznik koncepcie materiálneho jadra ústavy je reakciou diskurzu na túto kardinálnu pôvodnú chybu ústavy. Na tejto chybe majú svoj podiel viny aj tvorcovia ústavy z roku 1992, ktorí len mechanicky prebrali nedemokratickú koncepciu parlamentu ako jediného ústavodarného orgánu z obdobia spred roka 1990. Tvorcovia, žial', nezobrali do úvahy skutočnost', že parlament spred roka 1990 bol len fasádnou inštitúciou bez reálneho politického súperenia. Čo však mohlo byt' akceptované

${ }^{29}$ ROSANVALLON, P. Counter-Democracy, s. 116-117.

${ }^{30} \mathrm{H}$. Kelsen uviedol, že demokracia sa bez inštitucionálnej kontroly, ktorá zabezpečuje ústavnú legalitu, zrúti; KELSEN, H. The Essence and Value of Democracy. Plymouth : Rowman and Littlefield Publishers, 2013, s. 83.

${ }^{31}$ Por. napr. PROCHÁZKA, R. L’ud a sudcovia v konštitučnej demokracii, s. 121 a nasl.; CIBULKA, L'. Audit Ústavy Slovenskej republiky z pohl'adu 20 rokov jej vývoja. In Ústava Slovenskej republiky - 20 rokov v národnom a európskom meradle. Lutila : Lonfinger, 2012, s. 61-62.

${ }^{32}$ Napr. GINSBURG, T. - HUQ, A. How to Save a Constitutional Democracy. Chicago : The University of Chicago Press, 2018, s. 173. 
v roku 1992 ako demokratický štandard, určite nie je akceptované v roku 2021, ked' možnosti participatívnej demokracie a porovnávacieho ústavného práva sa rozvinuli do neobyčajných rozmerov. To, čo sa javí ako lepšie riešenie, sa vyvíja a nemôže byt' statické, preto trvat' na niečom, čo v súčasnosti už zjavne nezodpovedá demokracii, je nezmysel.

Niet preto divu, že od vzniku ústavy predstavitelia právnej doktríny, ale aj sám ústavný súd, sa pokúšali stanovit' hranice pre NR SR pri ústavodarnej činnosti. NR SR na tieto pokusy a návrhy nijako nereagovala viac ako 20 rokov. Tieto snahy sa zhmotnili práve v náleze PL. ÚS 21/2014, ktorým sa ústavný súd: (i) prihlásil k svojej judikatúre, ktorá deklaruje existenciu nemenitel'nej časti ústavy; (ii) čiastočne určil, čo do nej patrí; (iii) sám sa vyhlásil za štátny orgán, ktorý môže uvedené kontrolovat', a nakoniec (iv) nechal l'udu posledné slovo ohl'adom svojho sporu s NR SR. Posledným bodom nálezu sa mala ústava vrátit' l'udu (teda tam, kde skutočne patrí) a jeho rozhodnutím o legitímnom texte ústavy.

Týmto svojím krokom výrazne zvýšil rigiditu slovenskej ústavy, pretože navrhované ústavné zmeny nemohli menit' alebo rušit' nemenitel'né časti ústavy; ak by to NR SR nerešpektovala a kvalifikovaný subjekt by sa obrátil na ústavný súd, tak ústavný súd mohol ústavnú zmenu vyhlásit' za neústavnú. Tieto očividné prekážky dopĺn̆ala d’alšia: a to, že ak si NR SR myslí, že ide o legitímnu zmenu, tak má zorganizovat’ referendum o tejto zmene, pričom s definitívnou platnost'ou o legitimite zmeny rozhodne sám l'ud. Zastávam názor, že takéto rozhodnutie vylepšuje ústavný poriadok, zvyšuje rigiditu ústavy, zabezpečuje väčšiu kontrolu v ústavnom štáte a promuje demokraciu.

Práve referendum ako prejav priamej demokracie je ideálny prostriedok na zabezpečenie legitimity ústavnej zmeny, pretože ide o inštitút, ktorý umožňuje l'udu záväzne a nesprostredkovane vyjadrit' svoju vôl'u. Referendum je aktom zreálnenia l'udu a aktívneho sebaurčenia tu a teraz. Je o nás všetkých. V tom spočíva jeho legitimita a sila. ${ }^{33}$ Podstatou demokracie majú byt' spoločné akty chápania a konania, ktoré projektujú spoločné významy, hodnoty a symboly. ${ }^{34} \mathrm{~A}$ to sa môže stat' práve prostredníctvom priameho zapojenia l'udu do procesu ústavných zmien.

Nemyslím si, že l’ud má v referende schval’ovat' akúkol’vek zmenu ústavy. ${ }^{35}$ Avšak ak ide o podstatnú či dôležitú zmenu ústavy, ktorá sa týka kompetencie orgánov verejnej moci alebo statusu práv a slobôd, tak l'ud by mal byt' zapojený priamo. V pochybnostiach by sa malo použit' pravidlo, že l'ud je lepšie zapojit' ako nezapojit'. Nie je pritom dôležité, aký demokratický proces existoval pri vytvorení procesu zmien ústavy v pôvodnej verzii, l'ud si musí zachovat' spôsobilost' priamo participovat' na tvorbe ústavného práva. ${ }^{36}$

\footnotetext{
${ }^{33}$ Por. k referendu napr. TIERNEY, S. Sovereignty and Crimea: How Referendum Democracy Complicates Constituent Power in Multinational Societies. In German Law Journal, roč. 16, č. 3, 2015, s. 573-574.

${ }^{34}$ Por. ZIRK-SADOWSKI, M. Demokracja jako hermeneutyka. In Studia Prawno-Ekonomiczne, roč. 29, 1982, s. 20.

${ }^{35} \mathrm{O}$ tom, že demokratická legitimita nevyžaduje vždy referendum por. BECKMANN, L. Democratic legitimacy does not require constitutional referendum. On ,the constitution“ in theories of constituent power. In European Constitutional Law Review, roč. 14, 2018, s. 567.

${ }^{36}$ Otázka teda nestojí tak, či l’ud zapájat' do ústavných zmien, ale ako často, ako l'ahko a ako aktívne sa tak má robit'; HUTCHINSON, A. - COLÓN-RÍOS, J. Democracy and Constitutional Change. In Theoria: A Journal of Social and Political Theory, roč. 58, č. 127, 2011, s. 61.
} 
Nie je podstatné ani to, či samotná ústava formálne umožňuje zmenu v referende alebo nie. Zmena ústavy sa môže odohrávat' aj mimo rámca, ktorý je predvídaný samotnou ústavou. Napr. v podmienkach ústavného práva USA sa vedie dlhé roky diskusia o tom, či je možné menit' americkú ústavu aj iným režimom, ako predvída čl. V. Viacerí vplyvní autori sa prikláňajú $\mathrm{k}$ záveru, že americkú ústavu je možné zmenit' mimo rámca čl. V využitím nástrojov populárnej suverenity (napr. referenda). ${ }^{37}$

Demokracia sa týka zapojenia l'udu v určitej fáze tvorenia ústavy, jej doplnenia alebo zmeny. Ak je v tomto procese prítomný samotný l’ud ako suverén, tak aj neústavné pravidlo sa môže stat' ústavným, pretože sám suverén ho na také povýši svojím rozhodnutím, čím získa ultimátnu legitimitu. Ako napr. uvádza M. Tushnet, ustanovenie, ktoré bolo protiústavné v čase 1 , môže byt' ústavné v čase 2 , ak medzičasom bola realizovaná pôvodná ústavodarná moc. ${ }^{38}$

\section{AKÁ MÁ BYŤ ÚLOHA OCHRANCU ÚSTAVNOSTI V ÚSTAVNOM ŠTÁTE ALEBO O KONŠTITUCIONALIZME}

Podl'a vyššie uvedenej dôvodovej správy k ústavnému zákonu č. 422/2020 Z. z. má byt' táto rola ústavného súdu obmedzená. Vyplýva to z vyjadrení, že ústavný súd je „,produktom“ ústavy a svoju činnost' má vykonávat' len na základe ústavy. Toto vyjadrenie korešponduje s arogantným tvrdením ministerky spravodlivosti o tom, že: „Nie je namieste, aby nám ústavný súd hovoril, čo je ústava. “' ${ }^{39}$ Treba pripomenút', že demokratická erózia nastáva vždy vtedy, ak sa vládna moc snaží systematicky a úmyselne zbavit' kontroly zo strany iných zložiek mocí, predovšetkým súdov. ${ }^{40}$

Ako ukazujú negatívne príklady v Mad’arsku a Pol'sku, degradácia konštitucionalizmu nenastáva naraz, ale postupnými koordinovanými akciami, ktoré samy osebe by neznamenali osobitné ohrozenie a spektakulárnost', ale ich intenzita vedie k postupnému kolapsu inštitúcií demokratického a právneho štátu. ${ }^{41}$ Dokonca ani v týchto krajinách neprichádza k rušeniu právomocí ústavného súdu, ako to bolo v decembri $2020 \mathrm{v}$ NR SR. ${ }^{42}$ Nová právna úprava v krajinách, ku ktorým by Slovensko nechcelo patrit', sa snaží ochránit' tých, ktorí sú pri moci. Rule of law je nahrádzané rule by law. ${ }^{43}$

Dôležitý koncept tzv. negatívnej ústavy predstavuje F. Schauer. Rozlišuje tzv. primárne politické rozhodnutia (first-order policy decisions) a sekundárne dôsledky (second-

\footnotetext{
${ }^{37}$ Napr. TUSHNET, M. Taking Back the Constitution: Activist Judges and the Next Age of American Law. Yale : Yale University Press, 2020, s. 258-272.

${ }^{38}$ TUSHNET, M. Peasants with pitchforks, and toilers with Twitter: Constitutional revolutions and the constituent power, In ICON, roč. 13, č. 3, 2015, s. 653.

${ }^{39}$ Mária Kolíková: Nie je namieste, aby nám Ústavný súd hovoril, čo je ústava (podcast) | Aktuality.sk (stránka naposledy navštívená 7. januára 2021).

${ }^{40}$ Príklady por. GINSBURG, T. - HUQ, A. How to Save Constitutional Democracy, s. 98-101.

${ }^{41}$ Tamtiež, s. 24. Pre situáciu Pol'ska por. SADURSKI, W. Poland's Constitutional Breakdown. Oxford : Oxford University Press, 2019.

${ }^{42} \mathrm{~V}$ Mad'arsku môže tamojší ústavný súd posudzovat' aspoň procesné aspekty ústavných zákonov v zmysle čl. 24 ods. 1 a 2 mad'arskej ústavy z roku 2011.

${ }^{43}$ Zo široka por. publikáciu GINSBURG, T. - TAMIR, M. (eds.) Rule by Law. The Politics of Courts in Authoritarian Regime. Cambridge : Cambridge University Press, 2008.
} 
-order consequences). Konkrétne dáva do pozornosti, že ani rozhodnutia predstavitel'ov verejnej moci, ktorí robia rozumné primárne politické rozhodnutia, neznamená, že tie sú ústavne dovolené. Ani rozumnost', úprimnost' či verejný záujem konkrétnych politík ich nechráni od zrušenia na základe second-order dôvodov, ktoré nazývame ústavou. Ústavné rozhodovanie nie je o tom, aby sme sa chránili pred rozhodnutiami zlých l'udí, ktorí robia zlé rozhodnutia. Ústavné rozhodovanie je aj o tom, aby sme zabránili dobrým l'ud'om - politikom robit' rozumné politické rozhodnutia, ktoré majú negatívne sekundárne, inštitucionálne alebo iné dôsledky. Dobrí l’udia robiaci dobré veci často opomínajú nekonzekvencionálne hodnoty.

Ústava chráni dlhodobé hodnoty, ktoré sú osobitne ohrozené pri krátkodobých rozhodnutiach, preto vytvára sekundárne obmedzenia pre rozumné a dobre mienené primárne rozhodnutia. Ústava kontroluje dokonca aj najlepšie mienené demokratické rozhodnutia. Negatívna ústava predstavuje tie hodnoty, ktoré sú najviac ohrozené primárnymi rozhodnutiami. ${ }^{44}$

Aká by mala byt' intenzita kontroly parlamentu? Na pomoc si môžeme zobrat' štatistiky. V SRN vyhlási v priemere Spolkový ústavný súd zákon za neústavný približne 9-krát za rok. Vo Francúzsku v prípade Ústavnej rady sú štatistiky ešte vyššie. ${ }^{45} \mathrm{Na}$ druhej strane, na Slovensku Ústavný súd SR pristúpi k neústavnosti právnej úpravy ani nie 4 razy za rok (presne 3,5). ${ }^{46}$ Asi nikto racionálne uvažujúci nebude tvrdit', že slovenská legislatíva je v priemere viac ako dva razy lepšia ako nemecká alebo francúzska. Skôr bude platit', že ako v iných oblastiach (napr. v infraštruktúre, zdravotníckej starostlivosti či športe), sú Nemecko alebo Francúzsko „o míle“vpredu pred Slovenskom, podobne je to aj pri tvorbe legislatívy. Čo je odlišné medzi týmito krajinami, je zrejme asertívne uplatňovanie ústavy (vrátane doktrín vytvorených samotnými sudcami Spolkového súdu, resp. Ústavnej rady) voči politickým mociam v štáte. Dokonca prax predkladania zákonov v Nemecku je taká, že návrhy sa prispôsobujú existujúcej, ako aj predpokladanej budúcej judikatúre Spolkového ústavného súdu, čo niektorí komentátori nazývajú aj astrológiou z Karlsruhe. ${ }^{47}$

Preto hovorit' v tejto súvislosti o akejsi prehnanej aktivite slovenského ústavného súdu nie je namieste ani v rámci ústavného súdu, ani v akademickej obci. ${ }^{48}$ Dokonca nie je zrejmé, z akého dôvodu by ústavný súd mal napr. minimalizovat' svoj vplyv na rozhodnutia či proces iných orgánov, zdržanlivo uplatňovat' svoje právomoci, a tak pestovat' cnost' deferencie, či už v individuálnych ústavných st'ažnostiach ${ }^{49}$, alebo pri súlade kon-

${ }^{44}$ SCHAUER, F. Judicial Supremacy and the Modest Constitution. In California Law Review, roč. 92, 2004, s. 1055-1056.

${ }^{45}$ Por. GARDBAUM, S. What Makes for More or Less Powerful Constitutional Courts? In Duke Journal of Comparative \& International Law, roč. 29, č. 1, 2018, s. 5-6.

${ }^{46}$ Por. štatistiku do roku 2015 uvedenú v monografii LALÍK, T. Ústavný súd a parlament v konštitučnej demokracii, s. 207.

${ }^{47}$ Napr. VON BEYNE K. The German Constitutional Court in an Uneasy Triangle between Parliament, Government and Federal Leander. In SADURSKI, W. (ed.) Constitutional Justice East and West. Democratic Legitimacy and Constitutional Courts in Post-Communist Europe in a Comparative Perspective. Haag : Kluwer Law International, 2002, s. 110.

${ }^{48}$ Napr. KÁČER, M. - NEUMANN, J. Materiálne jadro v slovenskom ústavnom práve, s. 38-41.

${ }^{49}$ Medzi inými napr. I. ÚS 398/08. 
troly právnych predpisov. ${ }^{50}$ Práve naopak, ústavný súd je povinný chránit' ústavnost' ovel'a intenzívnejšie ako doteraz, pretože má na to aj demokratickú legitimitu (čast' Legitimita ústavného súdu).

$\mathrm{V}$ tejto súvislosti je možné priklonit' sa $\mathrm{k}$ preferencii vyššej morálnej ceny nadochrany ústavnosti a akceptovat' aktivistický ústavný súd v porovnaní s nižšou morálnou cenou pri nedostatočnej ochrane týchto hodnôt pri deferenčnom súde. Povedané inými slovami, z hl'adiska celkového stavu legitimity ústavy je lepší stav nadmernej ochrany ústavy ako riziko jej nepostačujúcej ochrany. Podl’a R. Fallona (aj ked’ trocha $\mathrm{v}$ inom kontexte) je $\mathrm{v}$ rámci tohto argumentu potrebné porovnat' predpokladaný počet chýb a morálnu cenu excesívnej ochrany s nedostatočnou ochranou ústavných hodnôt. ${ }^{51}$

Niekedy sa v slovenskom diskurze s právomocou ústavného súdu posudzovat' súlad ústavných zákonov spomína aj možnost' zneužitia tejto právomoci. ${ }^{52}$ Nie je celkom jasné, či ústavný súd v tomto konkrétnom prípade zneužil svoju právomoc. Žiadna publikácia sa tohto fenoménu nedotkla. Ako som uviedol skôr k žiadnemu zneužitiu neprišlo a, naopak, išlo o racionálne a podl'a mňa aj správne rozhodnutie, ktoré vyriešilo problém demokracie, ako aj rigidity ústavy. ${ }^{53}$

Po druhé, zostáva otázne, akým spôsobom by mohli sudcovia ústavného súdu zneužit' svoju moc. Aj ked' každá moc môže byt' apriori zneužitá, riziko medzi zneužitím moci parlamentu či exekutívy v porovnaní so zneužitím moci ústavným súdom je výrazne asymetrické. Úloha ústavného súdu ochraňovat’ ústavu je vždy inštrumentálna. Najväčšie riziko hrozí, že si ústavný súd môže posilnit' svoje postavenie voči iným orgánom verejnej moci a na úkor l’udu. Vo vzt’ahu k posilneniu na úkor iných orgánov verejnej moci sa žiadajú povedat’ dve veci. „Nadochrana“ ústavy nie je rizikom, ale, naopak, treba ju privítat'. To, že iné orgány musia rešpektovat’ ústavný súd a jeho judikatúru, je celkom prirodzené, pretože ústava je nadradená všetkým orgánom verejnej moci.

Vo vzt’ahu k vychýleniu moci medzi l'udom a ústavným súdom, ako vidiet', ústavný súd postavil l'ud nad seba. Teda moc l'udu stojí vyššie ako právomoci ústavného súdu, čo je v demokracii jediné možné riešenie. Z histórie mi nie sú známe situácie, ked’ by sa vrcholný súdny orgán stal akýmsi autokratom, zrušil iné orgány verejnej moci alebo urobil ich poslušným sebe. Naopak, história je plná príkladov, ked' parlament a exekutíva zrušili či rušia rôzne systémy efektívnej kontroly alebo sa snažia obsadit' personálny substrát „svojimi“ l'ud'mi. ${ }^{54}$

Po tretie a dôležitejšie, silné ústavné súdnictvo, ktoré sa začalo vytvárat’ po druhej svetovej vojne, bolo odpoved'ou na potrebu ochrany jednotlivca pred parlamentom a štátom ako celkom, a rovnako snahou zmiernit’ obrovskú nerovnováhu medzi štátom na

\footnotetext{
${ }^{50}$ Uznesenie sp. zn. PL. ÚS 11/2012, s. 70-71.

${ }^{51}$ Por. FALLON, R. The Core of an Uneasy Case for Judicial Review. In Harvard Law Review, roč. 121, č. 7, 2008, s. 1713-1715, ktorý neargumentuje ústavnost'ou, ale ochranou práv a slobôd, čo je čast'ou ústavnosti.

${ }^{52}$ KÁČER, M. - NEUMANN, J. Materiálne jadro v slovenskom ústavnom práve, s. 98.

${ }_{53}$ Por. LALÍK, T. The Slovak Constitutional Court on Unconstitutional Constitutional Amendment (PL. ÚS 21/2014). European Constitutional Law Review, roč. 16, č. 2, 2020.

${ }^{54}$ Čo môže byt' aj situácia prebiehajúcej súdnej reformy v podmienkach Slovenska.
} 
jednej strane a jednotlivcom na strane druhej. ${ }^{55}$ Práve zastupitel'ská forma demokracie v minulosti, ako aj súčasnosti predstavuje najväčšie riziko pre kultúru konštitucionalizmu, ústavu a v konečnom dôsledku aj pre demokraciu samotnú.

\section{LEGITIMITA ÚSTAVNÉHO SÚDU}

Na Slovensku sa málo píše o tom, že Ústavný súd SR má demokratickú legitimitu na svoju činnost'. Skôr sa diskurz zameriava na kontrapozície medzi legitimitou parlamentu na jednej strane a akousi nelegitimitou ústavného súdu na strane druhej, k čomu sa priklonila aj dôvodová správa. Ako si však neskôr ukážeme, takéto myslenie nie je správne.

Súdnu kontrolu ústavnosti a demokratickú legitimitu ústavného súdnictva treba chápat' v dvoch odlišných významoch. Demokratická legitimita ústavného súdu spočíva v rozšírení individuálnej legitimity jednotlivca, ktorý sa domáha ochrany svojich práv a slobôd prostredníctvom ústavného súdu. Tým, že ústavný súd chráni práva a slobody jednotlivcov proti štátu, je inštrumentom pre vindikáciu individuálnej legitimity. V tomto smere je demokratická legitimita rozšírením individuálnej legitimity, pretože individuálna legitimita je nevyhnutnou súčast'ou celkovej legitimity právno-politického systému. Nedostatočná ochrana práv a slobôd vedie k nelegitimite celého systému.

Druhý dôvod pre úzky vzt’ah medzi individuálnou a demokratickou legitimitou má formálny charakter. Právo namietat' právnu reguláciu, právo odporovat' právu (ako základné výrazy individuálnej legitimity) prostredníctvom súdneho systému je inštitucionálne zakotvené a je formálne regulované. Aby štát garantoval individuálnu legitimitu, musí vytvorit’ zodpovedajúcu inštitucionálnu základňu. Bez inštitúcií, ktoré chránia individuálnu legitimitu, by sa tá stala len ilúziou. Na druhej strane súdne konanie ovplyvňuje individuálnu legitimitu tým, že ju v konkrétnych prípadoch chráni alebo nechráni. Tak sú individuálna a demokratická legitimita spolu prepojené a vzájomne sa vynucujú. ${ }^{56}$

Demokratická legitimita súdnej kontroly ústavnosti sa nachádza v samotnom vnímaní demokracie. Demokracia znamená ovel’a viac ako len pravidlo väčšiny symbolizované jedinou inštitúciou: parlamentom. Demokracia je vel'mi zložitý koncept charakterizovaný neustálou evolúciou svojej vlastnej definície a redefinície svojich ciel’ov, obsahu a inštitúcií. Demokracia nie je ukončený projekt, nikdy neprestáva hl'adat' spôsoby a cesty, ako dat' l'udu hlas, ako ho splnomocňovat' a posilňovat'. ${ }^{57}$ Demokracia môže prekvitat' len vtedy, ak uzná svoju disfunkčnost' a vytvorí inštitúcie spôsobilé podrobit' svoje fungovanie konštruktívnemu hodnoteniu. ${ }^{58}$ Ústavné súdnictvo a súdna kontrola

\footnotetext{
${ }_{55}$ Medzi inými dielami napr. LUSTIG, D. - WEILER, J. Judicial review in the contemporary world Retrospective and prospective. In ICON, roč. 16, 2018, s. 329-332.

${ }^{56}$ MÖLLERS, CH. The Three Branches. A Comparative Model of Separation of Powers. Oxford : Oxford University Press, 2013, s. 64-78.

${ }^{57}$ Por. ROSANVALLON, P. Counter-Democracy, s. 2.

${ }^{58}$ Tamtiež, s. 74-75.
} 
ústavnosti sú dôležitými komponentmi demokratickej legitimity, ktorá by inak neexistovala. Judicial review nie je antidemokratické, ale, naopak, vylepšuje demokraciu. ${ }^{59}$

Jedným z argumentov v prospech demokratickej legitimity ústavných súdov je, že tieto rovnako sprítomňujú vôlu l'udu ako parlamenty a zabezpečujú spojenie medzi orgánmi verejnej moci a spoločnost'ou. Zastupovanie ako vzt'ah medzi l'udom a jeho zástupcami je základným konceptom demokracie a má inštitucionálny význam. ${ }^{60}$ Neobmedzuje sa pritom len na parlament, ale aj na iné inštitúcie vrátane ústavného súdu. Pri ústavnom súde je založený na kompetenciách, ktoré ústavné súdy vykonávajú.

Ako som už uviedol, l’ud je formálne bezmocný pred svojimi zástupcami. Avšak tým, že občania majú priamy prístup k ústavnému súdnictvu, majú právne prostriedky, ktoré im umožňujú kontrolovat' svojich zástupcov a vplývat' na výkon ich mandátu. D. Rousseau uvedenú koncepciu demokracie chápe ako kontinuálnu demokraciu, ktorá neruší zastupitel'ské formy, ale rozširuje možnosti na splnomocnenie a posilnenie l'udu pri výkone verejnej moci. ${ }^{61}$

V tejto súvislosti je možné mysliet' o prepojení medzi ústavným súdom a l’udom v dvoch rovinách. Pozitívna rovina demokratickej legitimity súdnej kontroly ústavnosti spočíva na vytvorení pocitu prináležitosti pre členov spoločnosti vyjadrením ústavných hodnôt a princípov pri súdnom rozhodovaní. Podl'a D. Grimma dáva súdna kontrola novú legitimitu demokratickému systému, ktorý je v permanentnej kríze. Západné spoločnosti stratili konsenzus, všeobecnú legitimitu a sociálne prepojenie. Všetko sa stalo nepredvídané. Tým, že ústavný súd robí viditel'né všeobecné a záväzné princípy, vytvára prepotrebný význam univerzálnosti aj pre tie skupiny, ktoré sa inak cítia odčlenené od mainstreamu ${ }^{62}$ Zastupovanie sa bytostne dotýka integrácie jednotlivcov do spoločnosti. ${ }^{63}$

Druhá rovina ústavného súdu ako zastupitel'ského orgánu má základ v ochrane l’udu pred svojimi zástupcami. Kl'účom je pochopit' to, že existujú dve vôle: vôl'a l'udu a vôl'a zástupcov, pričom vôl'a zástupcov nemôže byt' automaticky pripísaná vôli l’udu. Z časovej perspektívy vôl'a l'udu existuje aj po vol'bách, je neustále prítomná a vol'by sú jednorazovou udalost'ou, ked' je táto vôl'a rozpoznaná. Okrem toho, vôl'a l'udu je trvalo prítomná v ústave. Ak ústavné súdy vykonávajú kontrolu ústavnosti, chránia vôl'u l'udu pred zástupcom l'udu po obsahovej, ako aj časovej stránke. ${ }^{64}$ Ústavné súdy predstavujú tak dôležité tkanivo vzt'ahu medzi demokratickými inštitúciami a spoločnost'ou a sú bariérou spoločnosti a ochrany jej záujmov prostredníctvom ochrany individuálnej legitimity pred činnost'ou iných orgánov verejnej moci (predovšetkým parlamentu).

Demokratická legitimita súdnej kontroly ústavnosti sa môže zvýšit' svojimi účinkami. Tento predpoklad je plne v dispozícii samotných ústavných súdov, ktoré majú dis-

\footnotetext{
${ }^{59}$ Ústavný súd podl'a niektorých autorov nepatrí do sféry zastupitel'skej demokracie ale do sféry l'udu; ROUSSEAU, D. Sądownictwo konstytucyjne w Europie. Preklad Mirosław Granat. Varšava : Wydawnictwo sejmowe, 1999, s. 34-37.

${ }^{60}$ K tomu DAHL, R. Democracy and Its Critics. Yale : Yale University Press, 1989, s. 215.

${ }^{61}$ Por. ROUSSEAU, D. La démocratie continue. Paríž : L.G.D.J. Bruylant, 1995.

${ }^{62}$ GRIMM, D. Constitutionalism, s. 221.

${ }^{63}$ ARATO, A. Response to Melissa Williams. In Constellations, roč. 26, č. 1, 2019, s. 166.

${ }^{64}$ Por. ROUSSEAU, D. Sądownictwo konstytucyjne w Europie, s. 34-36.
} 
kréciu, ako široko alebo úzko vykonávat' kontrolu ústavnosti. Rozhodnutia môžu ovplyvnit' demokratickú spoločnost' viac ako jednotlivého st'ažovatel'a, pretože záujmy jednotlivca strácajú význam ako prípad stúpa v hierarchii súdneho systému, pričom sú minimálne pred vrcholnými súdmi. ${ }^{65}$ Dôsledky kontroly ústavnosti tak môžu mat' viac demokratické ako individuálne účinky. Ústavná st'ažnost' môže slúžit' ako pozvanie pre ústavný súd zasiahnut' široko do oblasti verejnej politiky. ${ }^{66} \mathrm{Na}$ jednej strane, ústavný súd má právomoc vyhlásit' celé politiky alebo inštitúcie za neústavné. Na druhej strane, súdy môžu zasa v rozhodnutiach predpisovat' určité politiky alebo regulácie, ktoré sú zákonodarca či výkonná moc povinní implementovat'. Pozitívne záväzky z l'udských práv sú dobrým príkladom. ${ }^{67}$ Ústavné súdy disponujú vel'kým potenciálom stat' sa spolutvorcami politických rozhodnutí v konkrétnej spoločnosti.

Ďalším spôsobom ako môžu ústavné súdy zvýšit' svoju demokratickú legitimitu, je úzko prepojená s pochopením statusu práva. Právo nie je považované za sväté. Od čias reformácie právo prestalo byt' prejavom Božej moci, pričom sa stalo produktom politiky. Vzt'ah medzi právom a politikou je vzt’ahom dispozície a dominancie: právo plní inštrumentálnu funkciu pre politiku a je jej plne podriadené. Podriadenost' politiky právu, ktorá existovala, ked' Boh bol pôvodcom celého práva, už neexistuje. ${ }^{68}$ Spochybňovanie a namietanie platnosti práva, jeho legitimity je niečo bežné. To, samozrejme, znamená, že aj politická väčšina sa môže ocitnút' na súde ako odporca. Ústavné súdy sú miestom, ktoré umožňuje začat' spor o platnost' a racionalitu práva.

Súčasný stav demokracie je taký, že je v permanentnej kríze, pričom mnohí autori neustále prichádzajú s novými nápadmi, ako túto krízu prekonat'. ${ }^{69}$ Demokracia v prvom rade potrebuje konštruktívne hodnotenie a musí sa zmierit' s vlastnou nefunkčnost'ou. ${ }^{70}$ Jedným zo symptómov krízy je nedostatok dôvery a dramatické zníženie legitimity čisto demokratických inštitúcií. Demokratická legitimita nemôže existovat', ak občania neveria svojim zástupcom a nemajú pocit, že sú splnomocnení konat'. ${ }^{71}$ Iní autori hovoria zasa o syndróme „unavenej demokracie“, ktorá je spojením nízkej volebnej účasti, znižujúcej

${ }^{65}$ Martin Shapiro tvrdí, že pred vrcholnými súdmi prinajhoršom sú sporové strany irelevanté, prinajlepšom sú príkladmi všeobecných problémov, ktoré je potrebné vyriešit; SHAPIRO, M. Courts. A Comparative and Political Analyses. Chicago : The University of Chicago Press, 1986, s. 56.

${ }^{66}$ V máji 2020 Spolkový ústavný súd vydal rozhodnutie (2 BvR 859/15 et al.), ktorým zabránil Spolkovej banke nakupovat' nemecké dlhopisy v rámci ozdravného programu Európskej centrálnej banky, ktorý mal zachránit' jednotnú európsku menu. Rozhodnutie bolo vydané v konaní o ústavnej st’ažnosti.

${ }^{67}$ Por. napr. rozsudok Spolkového ústavného súdu vo veci Hartz IV (BVerfGE 125,175-260) alebo rozsudok Ústavného súdu Kolumbie (sp. zn. T-760/2008), ktorý zreformoval celý systém zdravotnej starostlivosti.

${ }^{68}$ GRIMM, D. Constitutionalism, s. 199-200.

${ }^{69}$ Kríza demokracie existuje nepretržite od prvej svetovej vojny a reflektuje neschopnost' konceptualizovat' demokratickú legitimitu; por. ROSANVALLON, P. Democratic Legitimacy. Impartiality, Reflexivity, Proximity. Princeton : Princeton University Press, 2011, s. 32.

${ }^{70} \mathrm{~K}$ tomu ROSANVALLON, P. Counter-Democracy, s. 74.

${ }^{71}$ Jedným z dôvodov nedôvery zástupcov - vládcov je reálne fungovanie volieb, kde súčasní zástupcovia len zožali úspech nedôvery svojich oponentov a predchodcov. Voliči chcú potrestat' vládu minulých politikov. ROSANVALLON, P. Counter-Democracy, s. 175-176, ktorý to dokumentuje na Francúzsku, kde od roku 1981 každá vláda bola v nasledujúcich vol’bách odmietnutá bez ohl'adu na to, akú politiku robila. 
podpory pre politické strany a chronickou volebnou kampaňou. ${ }^{72}$ Ústavné inžinierstvo sa snaží túto nedôveru aj zinštitucionalizovat' v podobe súdnej kontroly ústavnosti.

Práve ústavné súdy sú inštitúciami, ktoré sú schopné hodnotit’ vnútorné chyby samotnej demokracie. V dnešnej spoločnosti, kde si žiadna inštitúcia nezaslúži úplnú dôveru, sú ústavné súdy súčast’ou inštitucionálnej nedôvery. ${ }^{73}$ Dôvod vytvorenia ústavného súdnictva môže byt' vnímaný z tejto perspektívy ako úloha neustále spochybňovat' platnost' a legitimitu práva (produkt politiky) tvorené parlamentom, ktorému nemôže byt' tak celkom dôverované. Nie je preto náhoda, že M. Kumm chápe ústavné súdy ako sokratovské inštitúcie, ktorých hlavná úloha spočíva v kontrole či konanie orgánov verejnej moci je založené na racionálnych dôvodoch. Akt donútenia musí byt' racionálne odôvodnený. ${ }^{74}$ Dôvody na obmedzenie musia byt' akceptované racionálne (nie ideologicky).

Tým, že parlament odobral ústavnému súdu právomoc posudzovat' súlad ústavných zákonov, neuplatnil racionálne argumenty, ale ideologické (parlament nepotrebuje inštitucionálnu kontrolu, pretože je suverén). Ako som už uviedol, ideologické argumenty majú chyby vo formálnoprávnej, ako aj v materiálnoprávnej rovine.

Inou oblast'ou, ktorú je možné priradit' k demokratickej legitimite ústavných súdov, je demokracia ako slobodný trh myšlienok založený na sút’ažení myšlienok a ideológií. Aby režim mohol byt' legitímny, musí akceptovat' diskusiu o všetkých právnych veciach. Neustále sút’aženie, výmena argumentov sú súčast'ou takto vnímanej demokracie. Základná premisa znie, že každá moc musí presvedčit' o svojej legitimite vo všetkých prípadoch tým, že sa aktívne zapojí do sút'aže myšlienok. ${ }^{75}$ Ide o preventívny liek pred tým, ako sa $\mathrm{z}$ demokracie stane totalitný štát alebo diktatúra. ${ }^{76}$

Súdne konanie o ideologických rozporoch je politickým procesom par excellence. Tieto politické procesy si však vynucujú všeobecnú (demokratickú) vôl'u v dvoch smeroch. Po prvé, možnost'ou demonštrovat' nedôveru kedykol'vek, čo periodicky zvyšuje všeobecnú dôveru. Po druhé, artikulované rozpory pri súdnej kontrole ústavnosti spochybňujú ilúziu jednotného l'udu vytvoreného numerickým procesom počítania hlasov. ${ }^{77}$

\footnotetext{
${ }^{72}$ Por. VAN REYBROUCK, D. Against Elections: The Case for Democracy. Londýn : Bodley Head, 2016, ktorý aj navrhuje možné riešenia tejto „únavy“ v podobe rôznych foriem priamej politickej participácie občanov: deliberatívne zoskupenia, občianske parlamenty, náhodný výber zákonodarcov, moderné technológie a iné. Riešenia ponúka aj J. Rancière: krátke a nebnovitel'né mandáty, ktoré nie je možné kumulovat'; zákaz kandidovania pre verejných funkcionárov; minimum volebnej kampane; prísna kontrola ekonomických síl vo volebných procesoch; RANCIÈRE, J. Nienawiść do demokracji. Varšava : Książka i Prasa, 2008, s. 89.

${ }^{73}$ Ani štát ako celok si nezaslúži „slepú dôveru“v tých najvypätejších situáciách. Napr. Alasdair MacIntire píše, že ak by mal moderný liberálny štát požadovat život svojich občanov, bolo by to ekvivalentné tomu byt' požiadaný zomriet' za telekomunikačnú spoločnost'. MACINTIRE, A. Poetry as Political Philosophy: Notes on Burke and Yeats. In BELL, V. - LERNER, L. (eds.) On Modern Poetry. Essays Presented to Donald Davie. Vanderbilt University Press, 1988, s. 149.

${ }^{74}$ KUMM, M. Insitutionalising Socratic Contestation: The Rarionalist Human Rights Paradigm, Legitimate Authority and the Point of Judicial Review. In European Journal of Legal Studies, roč. 1, č. 2 2007, s.166.

${ }^{75}$ Por. ROUSSEAU, D. The Conseil Constitutionnel confronted with comparative law and the theory of constitutional justice (or Louis Favoreu's untenable paradoxes). In ICON, roč. 5, č. 1, 2007, s. 42.

${ }^{76}$ Por. ZUPANČIČ, B. The Owl of Minerva. Essays on Human Rights. Utrecht : Eleven International Publishing, 2008, s. 396.

${ }^{77}$ ROSANVALLON, R. Counter-Democracy, s. 202.
} 
Základom demokratického štátu a jeho štruktúry je neustála konfrontácia rôznych myšlienok rozličnými sociálnymi skupinami a ekonomickými či politickými silami. ${ }^{78}$

Ako vidiet' $\mathrm{z}$ tohto prehl'adu, demokratickú legitimitu je potrebné chápat' dynamicky a spôsobom, ktorý berie do úvahy celkovú štruktúru štátu vrátane právneho a politického systému.$^{79}$ Ide o sumárnu rovinu, kde legitimita systému vyplýva z prepojení rôznych komponentov, ktorých celková suma vytvára systém, ktorý je podl’a svojich podmienok považovaný za legitímny. ${ }^{80}$

V tomto systéme má miesto aj súdna kontrola ústavnosti, ktorá zvyšuje celkovú legitimitu štátu, práva a spoločnosti. ${ }^{81}$ Ústavný súd je zastupitel'skou inštitúciou, ktorá umožňuje napádat' rozhodnutia, ktoré prijali volené inštitúcie. Demokratické rozhodnutie môže získat' alebo stratit' svoju legitimitu v tomto konaní. Súdna kontrola ústavnosti chápaná sensu largo je vlastne testom pre akékol'vek rozhodnutie. Je inštrumentom, ktorý zastupuje inštitucionálnu nedôveru v štáte. A nakoniec, môže mat' aj profylaktické účinky pre správne fungovanie orgánov verejnej moci do budúcnosti.

\section{K MATERIÁLNEMU JADRU ÚSTAVY}

V tejto časti nadviažem na diskusiu k materiálnemu jadru ústavy a osobitne sa zameriam na otázku, či je toto jadro výtvorom rozumu alebo vôle; akú úlohu hrá ústavný súd $\mathrm{v}$ projekte ústavy a, nakoniec, či je vhodnejšie za jadro považovat' l'udské práva namiesto čl. 1 ods. 1 ústavy.

Podl'a môjho názoru za neplodnú teóriu je možné považovat' diskusiu v otázke, či materiálne jadro ústavy je produktom rozumu alebo vôle. Problém materiálneho jadra nie je možné uchopit' len z jednej strany - vôl'a contra rozum, ako to robia autori M. Káčer a J. Neumann. ${ }^{82}$ Po prvé, na rozdiel od autorov, je možné uvažovat' o materiálnom jadre ústavy ako o produkte vôle. Ak prijmeme, že ústavný súd je aj pozitívny normotvorca, čo v súčasnom diskurze nemôže byt' sporné, tak voluntas sa tradične spája s tvorbou práva. Teda, ak ústavný súd vytvoril či použil materiálne jadro ústavy, konal ako normotvorca.

Okrem toho, ako uvádzajú právni teoretici, rozum a vôl'a nestoja v kontrapozícii. Aj vôl'a v podobe legislatívnej činnosti (tvorby práva) má totiž svoju rozumnost' (spravidla inštrumentálnu), a rovnako, rozum (ako rozhodovacia činnost' súdov a výtvory právnej doktríny) má svoju vôl'u. ${ }^{83}$ Rozdiely medzi oboma nie sú kategorické a vylučujúce sa, ale stupňovité (viac voluntas a menej ratia a vice-versa).

\footnotetext{
${ }^{78}$ Tamtiež, s. 15-16.

${ }^{79}$ Napr. BALKIN, J. Constitutional Redemption. Political Faith in an Unjust World. Harvard : Harvard University Press, 2011, s. 33.

${ }^{80}$ Por. PARKINSON, J. Deliberative systems. In BÄCHTIGER, A. a kol. (eds.) The Oxford handbook of deliberative democracy. Oxford : Oxford University Press, 2018, s. 434.

${ }^{81}$ Por. DWORKIN, R. Justice for Hedgehogs. Harvard : Harvard University Press, 2011, s. 385.

${ }^{82}$ Materiálne jadro v slovenskom ústavnom práve, s. 118-130.

${ }^{83}$ Pre podrobnosti por. dielo TUORI, T. Ratio and Voluntas. The Tension Between Reason and Will in Law. Londýn : Routledge, 2010.
} 
V súlade s autormi však materiálne jadro môže byt' aj prejavom rozumu ako určitý kvalitatívny ideál a podstata ústavy. Hl'adanie odpovede na otázku, či je materiálne jadro dôsledkom rozumu alebo vôle, považujem za neplodné, pretože nakoniec je možné uviest', že v oboch prípadoch - jadro ako produkt vôle alebo ako výtvor rozumu - postulát o jadre na jednej strane a o jeho zmene v referende nie je chybné uvažovanie, pretože vôl'a l'udu musí zostat' ultimátnym rozhodcom o tom, čo tvorí alebo netvorí najdôležitejšiu čast' ústavy, pretože l’ud je suverén (čl. 2 ods. 1 ústavy). ${ }^{84}$ Vôl'a ústavného súdu pri kreácii či deklarácii materiálneho jadra, resp. samotné materiálne jadro ako prejav rozumu, sú len sekundárne.

Kritiku si zaslúži aj názor časti právnej doktríny, že materiálne jadro ústavy sa v ústave nikde nenachádza a že jeho vytvorením sa vlastne nerešpektuje vôla pôvodného ústavodarcu a spochybňuje sa jeho racionalita. Teda, že ak by ústavodarca chcel vytvorit' toto jadro, tak by ho do ústavy jednoducho zakomponoval. ${ }^{85}$

Tento názor je príkladom prekonaného právneho pozitivizmu, ktorý chápe právo vrátane ústavy ako stabilný dokument, ktorý sa rozvíja výlučne činnost'ou orgánu alebo orgánov, ktoré tvoria právo v zmysle formálnom. Predmetný prístup však neberie do úvahy dva dôležité faktory. Prvým z nich je skutočnost', že aj súdy tvoria právo, a teda právny systém vrátane ústavy neustále aktualizujú, dotvárajú či dokonca vytvárajú. Táto činnost' pritom nie je sylogizmom, či mechanickou činnost'ou, ale aktom vôlovým, nevyhnutným a sčasti aj selektívnym. Nie je tu priestor na priblíženie tejto diskusie.

Druhým problémom uvedeného statického a formalistického pohl'adu na ústavu (ústava je len textom, ktorý je formálne v ústave zahrnutý) je ten, že nezohl’adňuje spoluzodpovednost' ústavného súdu za stav ústavy a právneho systému ako celku. Ústavný súd má dôležitú úlohu a zodpovednost' za to, ako vyzerá stav a recepcia ústavného práva, či už vo sfére politiky (ako najvyšší politickí hráči rešpektujú ústavu), práva (či iné orgány verejnej moci dodržiavajú ústavu a rozhodnutia ústavného súdu) či súdov (či súdne orgány zohl'adňujú prežarovanie ústavy právnym poriadkom). ${ }^{86}$

V tomto smere je zaujímavé, že predseda Najvyššieho súdu USA J. Roberts ešte ako kandidát na sudcu počas vypočutia pred senátnou Judicial Committee vysvetlil, ako vníma funkciu sudcu. Svoju rolu prirovnal športovou metaforou k rozhodcovi v baseballe, ked' uviedol, že jeho úlohou nie je pálkovat' alebo chytat' nadhody, ale len rozhodovat' o tzv. balloch a strikoch.

Táto metafora je silno kritizovaná pre mnohé dôvody ${ }^{87}$, ale najväčšia kritika prichádza za to, že baseballový rozhodca (ani akýkol’vek športový rozhodca) nie je zodpoved-

${ }^{84}$ Tiež stojí za zmienku, že mnohí autori a zástancovia parlamentu ako všemocného orgánu sa vôbec nezaoberajú formuláciou práve tohto ustanovenia ústavy a jeho vplyvu na ústavné zmeny a nevidia prepojenie medzi ústavou na jednej strane a suverenitou l'udu na strane druhej.

${ }^{85}$ PROCHÁZKA, R. L’ud a sudcovia v konštitučnej demokracii, s. 32 a n.; KÁČER, M. - NEUMANN, J. Materiálne jadro v slovenskom ústavnom práve, s. 89-91.

${ }^{86} \mathrm{~K}$ úlohe por. napr. publikáciu LANDFRIED, CH. (ed.) Judicial Power: How Constitutional Courts Affect Political Transformations. Cambridge : Cambridge University Press, 2019.

${ }^{87}$ Por. napr. MCKEE, T. Judges as Umpires. In Hofstra Law Review, roč. 35, 2007, s. 1709 a n. SIEGEL, N. Umpires at Bat: On Integration and Legitimation. In Constitutional Commentary, roč. 24, 2007, s. 704 a nasl. 
ný za kvalitu hry samotnej a je v podstate jedno, ako dobre/zle hráči alebo mužstvá hrajú. Úloha sudcu na vrcholnom súde taká určite byt' nemôže. Rola sudcu - osobitne na ústavnom súde - je kreatívna a spočíva $\mathrm{v}$ prispôsobovaní práva novým výzvam, technológiám, inštitúciám, ktoré zahŕňa aj hl’adanie a nachádzanie nových metód výkladov tých istých ustanovení. ${ }^{88}$ Sudca, ktorý akceptuje existujúce doktríny a kultúru práva, nebude robit' prácu, akú neustále vyvíjajúca sa spoločnost' od neho očakáva. ${ }^{89}$

Po tretie, namieste je zobrat' do úvahy aj konkrétnu činnost' slovenského ústavného súdu, ktorý dotvára a aktualizuje ústavu o právne normy a konštrukcie, ktoré ústava nepozná. Po príklady nemusíme chodit' d’aleko. Nález sp. zn. PL. ÚS 24/2014, ktorý vytvoril koncepciu, ked' l'udské práva môžu byt' predmetom referenda aj napriek kategorickej formulácii čl. 93 ods. 3 ústavy; rozhodnutie sp. zn. PL. ÚS 4/2012, ktorým vytvoril širokú mieru úvahy pre prezidenta posudzovat' kandidáta na generálneho prokurátora, ktorá sa v ústave nikde nenachádza; podobne v náleze II. ÚS 171/05 uviedol, že vstup Slovenska do štátneho zväzku s iným štátom sa môže uskutočnit’ len slobodne a pod podmienkou, že vstup bude rešpektovat' ústavnoprávne normy (najmä čl. 1 ods. 1 ústavy), alebo rozhodnutia, ktorými ústavný súd povýšil právo EÚ nad ústavu aj napriek zneniu čl. 7 ods. 2 ústavy, ktorý predpokladá opak. ${ }^{90}$

Tieto a d'alšie rozhodnutia majú spoločné to, že ústavný ústavu dotvoril, resp. vytvoril také normy, ktoré ústavodarca nielenže nepredvídal v roku 1992, ale ani predvídat' nemohol. Tie sú súčast’ou ústavy, kým ich ústavný súd sám neprekoná alebo ich neprekoná delegovaný ústavodarca. ${ }^{91}$ Preto rozhodnutie PL. ÚS 21/2014, ktorým ústavný súd zrušil čast' ústavy, je len jedným z mnohých rozhodnutí, kde ústavný súd chápe svoju úlohu kreatívne, čo je v súlade so súčasným konštitucionalizmom. Koncept materiálneho jadra ako takého nebol vytvorený v tomto náleze, ale išlo o postupnú gradujúcu činnost', ktorá vyvrcholila v náleze sp. zn. PL. ÚS 7/2017, kde materiálne jadro ústavný súd formuloval extenzívne. ${ }^{92}$

Ústava $\mathrm{v}$ tomto smere nie je raz a navždy kompletný dokument. Naopak, ústava je objektom evolúcie spoločnosti, práva a aktérov verejnej moci. Ako uvádza B. Constat, musí v nej samej ostat' priestor, aby čas a skúsenost' mohli ústavu vylepšit' nielen v tom, čo sa stalo, ale aj v tom, čo sa ešte má stat'. Aj takto je možné nahliadat' na koncepciu materiálneho jadra ústavy, zvýšenia rigidity ústavy a úlohy l'udu v ústavnom projekte.

Opätovne je možné pomôct' si Nemeckom. Spolkový ústavný súd vo svojom slávnom rozhodnutí o Lisabonskej zmluve z roku 2009 formuloval dve osobitné konania,

\footnotetext{
${ }^{88} \mathrm{~K}$ úlohe právnikov por. inauguračnú prednášku ŁĘTOWSKEJ, E. Communicare et humanum, et necesse est - o komunikacyjnej misji muzyków i prawników. In Monitor prawniczy, č. 12005.

${ }^{89}$ Por. POSNER, R. Divergent Paths. The Academy and the Judiciary. Cambridge : Harvard University Press, 2016, s. 162-163.

${ }^{90}$ Nález sp. zn. PL. ÚS 3/09 potvrdený aj v uznesení sp. zn. PL. ÚS 37/2015.

${ }^{91} \mathrm{~K}$ tomu viac nález sp. zn. PL. ÚS 7/2017.

${ }^{92} \mathrm{~V}$ tomto smere je zaujímavé, že doktrinálny disent autorov M. Káčera a J. Neumanna k nálezu PL ÚS 21/2014 neuviedol túto podstatnú skutočnost' a poprípade ju kriticky zhodnotil práve vo vzt’ahu k rozhodnutiu PL. ÚS 7/2017. Autori postupujú tak, ako keby nález PL. ÚS 21/2014 bol prvým, ktorý prišiel s koncepciou materiálneho jadra. Opak je pravdou. Potvrdenie zrušených amnestií PL. ÚS 7/2017 otvorilo dvere k PL. ÚS 21/2014. Zrušenie sudcovských previerok by nemohlo vzniknút', ak by nebol nález PL. ÚS 7/2017.
} 
ktoré nie sú obsiahnuté ani v Základnom zákone ani v zákone o spolkovom ústavnom súde, a ktoré majú za ciel' umožnit' Spolkovému ústavnému súdu kontrolovat pôsobenie práva EÚ v Nemecku. Konkrétne Spolkový ústavný súd môže posudzovat’ to, či orgány EÚ nekonajú ultra vires, a takisto, či právne akty EÚ nezasahujú do ústavnej identity SRN bez toho, aby mal na to nejaké osobitné zmocnenie okrem ochrany ústavnosti.

Do veci PL. ÚS 21/2014 ústavný súd nemal prípad, kde by navrhovatel' priamo namietal porušenie ústavy, resp. jej jadra ústavným zákonom. ${ }^{93}$ Ďalším faktorom v prospech teórie o neústavných ústavných zákonoch je akcelerovaný vývoj v slovenskej a svetovej právnickej doktríne, ktorá sa týmto fenoménom posledných 10 rokov vel'mi intenzívne zaoberá, pričom jednoznačne prevažuje názor, že ústavné súdy sú oprávnené posudzovat' súlad ústavného zákona s ústavou bez ohl'adu na existenciu večnej klauzuly, resp. bez ohl'adu na výslovnú právomoc tak robit'. ${ }^{94}$

Na základe uvedeného je možné uviest', že ústavný súd materiálne jadro použil, aby naplnil svoju úlohu ochrancu ústavy pred jej eróziou zo strany parlamentu, ktorý neprejavuje patričný rešpekt pred ústavnými zmenami, používa ich na krátkodobé ciele, čo stiera rozdiely medzi ústavou a bežnou legislatívou, čím parlament nechápe správne svoje miesto medzi orgánmi verejnej moci. V skratke, ak parlament nie je schopný sebareflexie pri ústavnej normotvorbe, potrebuje externú kontrolu ako každý iný orgán verejnej moci.

Ďalšou vecou, na ktorú chcem poukázat', predstavuje obsah materiálneho jadra ústavy. Autori M. Káčer a J. Neumann vidia tento obsah nie v čl. 1 ods. 1 ústavy, ale v celej druhej hlave, teda, že do jadra patria l’udské práva a slobody, a nie princípy právneho štátu a demokracia. Argumentujú, že takéto jadro ústavy je menej amorfné, pretože katalóg je podrobnejší (ústavný súd má menšiu diskréciu), pri obmedzovaní sa používa test proporcionality, ktorý štruktúruje argumentáciu súdu, l'udské práva sú regulované aj na medzinárodnej úrovni, čo má robit’ ústavnoprávnu komparáciu spol’ahlivejšou, a, nakoniec, l'udské práva sú práve požiadavkou suveréna v dejinných okolnostiach novembrovej revolúcie. ${ }^{95}$

Na prvý pohl'ad sa môže zdat', že idea l'udských práv ako jadra ústavy je atraktívnejšia. Avšak zdanie často klame. L’udské práva sú rovnako abstraktné hodnoty ako právny štát alebo demokracia. Osobne nepoznám právnu situáciu, ktorá by sa l'udských práv priamo nedotýkala. ${ }^{96}$

\footnotetext{
${ }^{93}$ Vec sp. zn. II. ÚS 153/2013 za takú považovat' nemožno aj vzhl'adom na neexistenciu prepojenia konania o ústavnej st’ažnosti s konaním o súlade právnych predpisov.

${ }^{94}$ Koniec koncov aj doktrinálny disent M. Káčera a J. Neumanna či prístup R. Procházku s neústavným ústavným zákonom rátajú.

${ }^{95}$ Materiálne jadro v slovenskom ústavnom práve, s. 133-136.

${ }^{96}$ Symptomatickým môže byt' vývoj priznávania l'udských práv zvieratám v niektorých krajinách (napr. Kolumbia), živým prvkom prírody - národným parkom, riekam, lesom, pohoriam (napr. PALACIO, J. - HERRERA, J. First Rivers, then Mountains, and Now the Amazon. Do "Things" Have Rights? [2021-02-03]. Dostupné na internete: $<\mathrm{I} \cdot$ CONnect - First Rivers, then Mountains, and Now the Amazon. Do "Things" Have Rights? (iconnectblog.com> alebo diskusia medzi právnymi teoretikmi v 50. rokoch v SRN o tom, či zastavenie vozidla na červené svetlo na svetelnej križovatke porušuje l'udskú dôstojnost', ked’že o slobode človeka rozhoduje automat (SCHREITER, M. Gehorsam für automatische Farbzeichen - ein Beitrag zum Roboterproblem. Die Öffentliche Verwaltung, roč. 9, 1956, s. 692
} 
Z titulu rozsahu druhej hlavy ústavy (najväčšia čast') by sa dalo povedat', že pravdepodobnost' neústavných ústavných zákonov sa ešte ceteris paribus zvýši v porovnaní s čl. 1 ods. 1 ústavy.

Aj vec PL. ÚS 21/2014 sa dala poňat' ako l'udskoprávna otázka, čo viackrát spomína aj samotný ústavný súd v náleze. Ak by navrhovatel'ka uviedla ako referenčné kritériá povedzme čl. 46 ods. 1 alebo čl. 19 ods. 2 ústavy, ústavný súd mohol urobit' identický záver o časti ústavného zákona č. 141/2014 Z. z. dokonca s podobnou argumentáciou. V prvom rade je pre právnikov celkom prirodzené v rámci svojho povolania preniest' všetky aspekty obyčajného l'udského sporu a vytvorit' z neho právny spor, ktorý sa stane objektom právnickej debaty. Akúkol'vek ujmu jednotlivca je v celku jednoduché preniest' na úroveň obmedzenia práv či slobôd. Korelujúcou čast'ou celej koncepcie ústavného jadra je potom vôl'a ústavných sudcov prípad prejednat' a ochránit' ústavnost'. ${ }^{97}$

Z hl'adiska medzinárodnoprávnej ochrany l’udských práv sa tento štandard často prezentuje v slovenskej teórii, aj v praxi ako ten najvyšší. Opak je pravdou, medzinárodná ochrana práv a slobôd poskytuje len minimálnu úroveň ochrany, a štáty majú poskytovat' širšiu ochranu jednotlivcom, ako to robí medzinárodné právo. ${ }^{98}$ Štandard tvorený ESL'P je nutné minimum a Slovensko má chránit' práva a slobody vel'korysejšie. ${ }^{99}$ Teda argument o medzinárodnom rozmere je dôležitý, ale nemôže byt' určujúci pre ústavné právo na Slovensku.

Podobné argumenty je možné uviest' $\mathrm{k}$ testu proporcionality a osobitne k vyvažovaniu, ktoré umožňuje širokú mieru diskrécie pre sudcu a robí z neho politika, a nie právnika, kde sudca si vlastne vyberá riešenia podl'a svojich kritérií. ${ }^{100}$ Samozrejme, test proporcionality do istej miery zvyšuje transparentnost', ale takým môžu byt' aj „obyčajný“ výklad práva a právnická argumentácia. Nie je mi celkom zrejmé, v čom sa principiálne má odlišovat' váženie konfliktujúcich záujmov od „tradičného“ výkladu práva. Obe činnosti sú v podstate výkladom práva a právnickou argumentáciou.

Teda, v konečnom dôsledku test proporcionality ani l'udské práva, či medzinárodnoprávna ochrana práv a slobôd nie sú lepšou alternatívou k materiálnemu jadru ústavy,

\footnotetext{
${ }^{97}$ Tu je možné ešte uviest', že vlastne celá úloha ústavného súdu je binárna - či niečo je v súlade s ústavou alebo nie je, pričom l'ahšie sa v princípe hl'adajú argumenty, prečo je ústavnost' porušená, pretože negatívna argumentácia (popieranie) je ovel’a jednoduchšia z titulu slobody použit' akýkol’vek argument.

${ }^{98}$ Ako pozitívny prípad je možné opät' uviest' Nemecko a ochranu práva na súkromie, kde bezpečnostné úrady na základe zákona mohli požadovat' od telefonických spoločností dátové údaje o odberatel'och. Identický prípad rozhodoval najprv ESL'P (Breyer c. SRN, st’ažnost' č. 50001/12, rozsudok z 30. januára 2020) a až potom rozhodol Spolkový ústavný súd (27. mája 2020, sp zn. 1 BvR 1873/13 a 1 BvR 2618/13). Kým ESL'P skonštatoval neporušenie čl. 8 Dohovoru, Spolkový ústavný súd právnu úpravu zrušil pre rozpor s právom na súkromie a informačným sebaurčením jednotlivca. Postupoval by rovnako aj slovenský ústavný súd?

${ }^{99}$ Takto treba vnímat' aj nedávne rozhodnutie ESL’P z 9. februára 2021 vo veci Xhoxhaj c. Albánsko, st’ažnost' č. 15227/19, kde ESLP skonštatoval, že komplexné sudcovské previerky nie sú v rozpore s namietanými článkami Dohovoru. K tomuto rozsudku pripojili dvaja sudcovia svoje disenty a nie je vylúčené, že sa prípad nedostane pred Vel'kú komoru.

${ }^{100}$ Napr. SADURSKI, W. „Rozumność” między teorią prawa a filozofią polityczną. In WYRZYKOWSKI, M. (ed.) Rozumność rozumowań prawniczych. Varšava, 2008, s. 9 a nasl.
} 
pretože nijako neznižujú diskréciu ústavného súdu. Ak tak len rétoricky možno l’udské práva nemajú v našej doktríne taký cveng ako materiálne jadro, čo by mohlo ústavný súd skôr odradit' od vyhlásenia neústavného zákona s ústavou. Čo však nie je správny prístup.

Preto nie je namieste viest' spory, či obsah jadra tvoria také hodnoty alebo hodnoty iné. Aj v krajinách, ktoré majú večnú klauzulu, je tajomstvom, čo konkrétne do klauzuly patrí a s čím môže byt' ústavný zákon potenciálne v rozpore. Delegovaný ústavodarca si tak nie je istý. Spor preto neprebieha v deskriptívnej či analytickej rovine, ale na úrovni doktrinálnej a praktickej. V tej praktickej otázka stojí tak, či je ústavný súd ochotný a schopný chránit' ústavnost' aj pred parlamentom, ktorý vystupuje v prezlečení všemocného suveréna, a íst' s ním do otvoreného konfliktu. V doktrinálnej zasa spor prebieha o úlohe, ktorú má ústavný súd v ústavnom štáte plnit', ako aj o metódach výkladu práva, ktoré môže pri tom uplatňovat'.

\section{ZÁVER}

Ako som už vel'akrát uviedol vo svojich článkoch, kl'účom k ústavnému štátu je taká ústavná kultúra, ktorá rešpektuje rozhodnutia ústavného súdu, nech by boli akékol'vek. Pre mňa najvýstižnejšie tento základ vyjadrila bývala spolková ministerka spravodlivosti B. Zypriesová pri príležitosti 60. narodenín Základného zákona: „Ak je SRN považovaná za osobitne úspešnú v porovnaní s Weimarskou republikou nie je to preto, žeby text a obsah Základného zákona boli ovel'a lepšie ako vo Weimarskej republike. Podstatné je, že garantom úspechu je primárne kultúra, ktorá zahŕña vôlu mocných l’udí v politike a vo vláde postupovat'v súlade so Základným zákonom a rešpektovat' kontrolu svojho postupu zo strany Spolkového ústavného súdu. (...) Ak polemika spochybřuje legitimitu súdu a v spojení s ňou nerešpektovanie jeho rozhodnutia, ide o nebezpečenstvo ničiace našu ústavnú kultúru. " 101 Osobitne, ak ide o rozhodnutie ústavného súdu, ktoré vylepšuje ústavný poriadok tým, že zvyšuje rigiditu pre ústavné zmeny, zabraňuje parlamentnej svojvôli a podporuje demokraciu.

Tento dlhodobý postoj rešpektu vidiet' aj v udalostiach minulého roka, ktoré sa stali v Nemecku. V máji 2020 Spolkový ústavný súd vydal rozhodnutie (2 BvR 859/15), ktorým zabránil Spolkovej banke nakupovat' nemecké dlhopisy v rámci ozdravného programu Európskej centrálnej banky, ktorý mal zachránit’ jednotnú európsku menu. Dôvodom bolo, že tento program nebol podrobne zdôvodnený Európskou centrálnou bankou z titulu proporcionality a Súdny dvor EÚ tento test v rozhodnutí Gauweiler metodologicky nesprávne uplatnil (a uplatn̆uje). ${ }^{102} \mathrm{Aj}$ napriek obrovskej kritike tohto rozhodnutia z celej

${ }^{101}$ ZYPRIES, B. The Basic Law at 60 - Politics and the Federal Constitutional Court. In German Law Journal, roč. 11, č. 1, 2010, s. 95-96.

102 Zaujímavost'ou je, že toto rozhodnutie vydal druhý senát, ktorého predsedom a zároveň predsedom celého Spolkového ústavného súdu bol A. Voßkuhle. V tejto súvislosti sa nemecká kultúra rešpektu prejavila aj v tom, že ked' sa predsedovi súdu skončilo funkčné obdobie 22. júna 2020, od nemeckého prezidenta dostal vysoké štátne vyznamenania. Urobili by niečo také napr. prezident A. Kiska alebo prezidentka Z. Čaputová voči bývalej predsedníčke ústavného súdu I. Macejkovej? 
Európy ${ }^{103}$, ako aj Nemecka, sa rozhodnutie Spolkového ústavného súdu rešpektovalo a vykonalo (Európska centrálna banka prvýkrát v histórii zdôvodnila svoje rozhodnutie). ${ }^{104}$

Je zrejmé, že ústavné súdy nezachránia demokraciu pred eróziou, resp. od jej premeny na neliberálnu formu. Zásah súdu je skôr dôležitý ako prevencia tejto degradácie $e x$ ante, čo je akceptovatel'né a efektívne riešenie. ${ }^{105} \mathrm{Na}$ druhej strane, zapojenie l'udu do zmien ústavy je prejavom demokratického charakteru štátu a symbolom, komu v štáte reálne patrí všetka moc. Ako hovorí delegovaný ústavodarca - poistkou proti neústavným ústavným zákonom sú l'ud a vol'by - avšak s tým dôvetkom, že to má byt' l'ud sám $\mathrm{v}$ referende, a nie jeho fingovaný zástupca. V tejto konštelácii je nejasné, prečo sa politické elity na Slovensku tak vel'mi bránia pred väčším využívaním priameho zapojenia l'udu do rozhodovania. Ako hovoria empirické skúsenosti, občania Slovenska si vždy vybrali správne. ${ }^{106} \mathrm{Aj}$ ked' rozhodnutia suveréna nie sú predmetom hodnotenia v kategóriách správnosti alebo nesprávnosti (pretože ide o suveréna), l'ud má v ústavnom práve našej krajiny obrovský potenciál, ktorý aj po 30 rokoch zostáva nevyužitý. Našt'astie má ústavný súd viac času ako volení politici a množstvo príležitostí (okrem RvP 2879/2020), aby kritizovanú formuláciu čl. 125 ods. 4 ústavy derogoval a d’alej pokračoval vo vylepšovaní slovenskej ústavy.

\section{Literatúra}

ARATO, A.: Response to Melissa Williams. In Constellations, roč. 26, č. 1, 2019

BALKIN, J.: Constitutional Redemption. Political Faith in an Unjust World. Harvard: Harvard University Press, 2011

BECKMANN, L.: Democratic legitimacy does not require constitutional referendum. On 'the constitution' in theories of constituent power. In European Constitutional Law Review, roč. 14, 2018

BREICHOVÁ - LAPČÁKOVÁ, M.: Vplyv referenda na zvýšenie demokratickej legitimity ústavných zmien - Návrhy de constitutione ferenda v kontexte československých ústavných dejín. In Grant Journal, roč. 8, č. 2,2020

CIBULKA, L': Audit Ústavy Slovenskej republiky z pohl’adu 20 rokov jej vývoja. In Ústava Slovenskej republiky -20 rokov v národnom a európskom meradle. Lutila: Lonfinger, 2012

COLÓN - RÍOS, J.: Arato's Adventures: between sovereignty and constituent power. In Journal for constitutional theory and legal philosophy, 41/2020, § 25-27 [2021-02-03]. Dostupné na internete: $<$ https://journals.openedition.org/revus/6257>

DAHL, R.: Democracy and Its Critics. Yale: Yale University Press, 1989

DWORKIN, R.: Justice for Hedgehogs. Harvard: Harvard University Press, 2011

ELLIOTT, M.: Constitutional Adjudication and Constitutional Politics in the United Kingdom: The Miller II Case in Legal and Political Context. In European Constitutional Law Review, roč. 16, č. 4, 2020

${ }^{103}$ Podstatná čast' časopisu German Law Journal roč. 21, č. 5, 2020, sa v sekcii The German Federal Constitutional Court's PSPP Judgmen v podstate venuje len kritike tohto rozhodnutia.

${ }^{104}$ A ešte jedna perlička - Spolkový ústavný súd takéto rozhodnutie urobil v ústavnej st’ažnosti, ktorým st’ažovatelia namietali porušenie svojho aktívneho volebného práva. Trúfol by si na niečo také slovenský ústavný súd?

${ }^{105}$ GINSBURG, T., HUQ, A. How to Save Constitutional Democracy, s. 97.

${ }^{106}$ Por. k tomu BREICHOVÁ - LAPČÁKOVÁ, M. Vplyv referenda na zvýšenie demokratickej legitimity ústavných zmien - Návrhy de constitutione ferenda v kontexte československých ústavných dejín. In Grant Journal, roč. 8 , č. 2, 2020, s. 35 an. 
FALLON, R.: The Core of an Uneasy Case for Judicial Review. In Harvard Law Review, roč. 121, č. 7, 2008

GARDBAUM, S.: What Makes for More or Less Powerful Constitutional Courts ? In Duke Journal of Comparative\& International Law, roč. 29, č. 1, 2018

GINSBURG, T., HUQ, A.: How to Save a Constitutional Democracy. Chicago: The University of Chicago Press, 2018

GRIMM, D.: Constitutionalism. Past, Present, and Future. Oxford: Oxford University Press, 2016

HUTCHINSON, A. - COLÓN-RÍOS, J: Democracy and Constitutional Change. In Theoria: A Journal of Social and Political Theory, roč. 58, č. 127, 2011

KÁČER, M., NEUAMNN, J.: Materiálne jadro v slovenskom ústavnom práve. Doktrinálny disent proti zrušeniu sudcovských previerok. Praha: Leges, 2019

KELSEN, H.: The Essence and Value of Democracy. Plymouth: Rowman and Littlefield Publishers, 2013

KOKEŠOVÁ, J.: Ústavní soud a reprezentace lidu: abduktivní interference. In Právník, č. 6, 2019

KUMM, M.: Insitutionalising Socratic Contestation: The Rarionalist Human Rights Paradigm, Legitimate Authority and the Point of Judicial Review. In European Journal of Legal Studies, roč. 1, č. 22007

LANDFRIED, CH. (ed.) Judicial Power: How Constitutional Courts Affect Political Transformations. Cambridge: Cambridge University Press, 2019

LUSTIG, D., WEILER, J.: Judicial review in the contemporary world - Retrospective and prospective. In ICON, roč. 16,2018

LALÍK, M., L'ALÍK, T.: Zákon Ústavnom súde Slovenskej republiky. Komentár. Bratislava: Wolters Kluwer, 2019

LALÍK, T.: The Slovak Constitutional Court on Unconstitutional Constitutional Amendment (PL. ÚS 21/2014). European Constitutional Law Review, roč. 16, č.2, 2020

LALÍK, T.: Ústavný súd a parlament v konštitučnej demokracii. Bratislava: Wolters Kluwer, 2015

MACINTIRE, A. Poetry as Political Philosophy: Notes on Burke and Yeats. In BELL, V., LERNER, L. (eds.) On Modern Poetry. Essays Presented to Donald Davie. Vanderbilt University Press, 1988

MCKEE, T.: Judges as Umpires. In Hofstra Law Review, roč. 35, 2007

MORAWSKI, L.: Zasady wykładni prawa. 2. wyd. Toruň: Dom Organizatora, 2010

MÖLLERS, CH.: The Three Branches. A Comparative Model of Separation of Powers. Oxford: Oxford University Press, 2013

OBER, J.: The Original Meaning of "Democracy“: Capacity to Do Things, not Majority Rule. In Constellations, roč. 15, č. 1,2008

PARKINSON, J.: Deliberative systems. In BÄCHTIGER, A. a kol. (eds.) The Oxford handbook of deliberative democracy. Oxford: Oxford University Press, 2018

POSNER, R.: Divergent Paths. The Academy and the Judiciary. Cambridge: Harvard University Press, 2016

PROCHÁZKA, R.: L'ud a sudcovia v konštitučnej demokracii. Plzeň: Aleš Čeněk, 2013

RANCIÈRE, J.: Nienawiść do demokracji. Varšava: Książka i Prasa, 2008

ROSANVALLON, P.: Democratic Legitimacy. Impartiality, Reflexivity, Proximity. Princeton: Princeton University Press, 2011

ROSANVALLON, P.: Counter-Democracy. A Politics in an Age of Distrust. Cambridge: Cambridge University Press, 2012

ROUSSEAU, D.: La démocratie continue. Paríž: L.G.D.J. Bruylant, 1995

ROUSSEAU, D.: Sądownictwo konstytucyjne w Europie. Preklad Mirosław Granat. Varšava: Wydawnictwo sejmowe, 1999

ROUSSEAU, D.: The Conseil Constitutionnel confronted with comparative law and the theory of constitutional justice (or Louis Favoreu's untenable paradoxes). In ICON, roč. 5, č. 1, 2007

SADURSKI, W.: „Rozumność” między teorią prawa a filozofią polityczną. In WYRZYKOWSKI, M. (ed.) Rozumność rozumowań prawniczych. Varšava: 2008

SIEGEL, N.: Umpires at Bat: On Integration and Legitimation. In Constitutional Commentary, roč. 24, 2007

SHAPIRO, M.: Courts. A Comparative and Political Analyses. Chicago: The University of Chicago Press, 1986

SCHAUER, F.: Judicial Supremacy and the Modest Constitution. In California Law Review, roč. 92, 2004

Právny obzor $2 / 2021$ 
SCHREITER, M.: Gehorsam für automatische Farbzeichen — ein Beitrag zum Roboterproblem. Die Öffentliche Verwaltung, roč. 9, 1956

SZYMANEK, J.: Mandat parlamentarny (reinterpretacja ujęć klasycznych). In Przegłąd sejmowy, roč. 100, č. 5,2010

TIERNEY, S.: Sovereignty and Crimea: How Referendum Democracy Complicates Constituent Power in Multinational Societies. In German Law Journal, roč. 16, č. 3, 2015

TUORI, T.: Ratio and Voluntas. The Tension Between Reason and Will in Law. Londýn: Routledge, 2010

TUSHNET, M.: Peasants with pitchforks, and toilers with Twitter: Constitutional revolutions and the constituent power. In ICON. roč. 13, č. 3, 2015

TUSHNET, M.: Taking Back the Constitution: Activist Judges and the Next Age of American Law. Yale: Yale University Press, 2020

VAN REYBROUCK, D.: Against Elections: The Case for Democracy. Londýn: Bodley Head, 2016

VON BEYNE K.: The German Constitutional Court in an Uneasy Triangle between Parliament, Government and Federal Leander. In SADURSKI, W. (ed.) Constitutional Justice East and West. Democratic Legitimacy and Constitutional Courts in Post-Communist Europe in a Comparative Perspective. Hág: Kluwer Law International, 2002

ZIRK-SADOWSKI, M.: Demokracja jako hermeneutyka. In Studia Prawno-Ekonomiczne, roč. 29, 1982

ZUPANČIČ, B.: The Owl of Minerva. Essays on Human Rights. Utrecht: Eleven International Publishing, 2008

ZYPRIES, B.: The Basic Law at 60 - Politics and the Federal Constitutional Court. In German Law Journal, roč. 11 , č. 1,2010 